\title{
Stratigraphy, mammalian paleontology, paleoecology, and age correlation of the Wasatch Formation, Fossil Butte National Monument, Wyoming
}

\author{
Gregg F. Gunnell, ${ }^{1}$ John-Paul Zonneveld, ${ }^{2}$ and William S. Bartels ${ }^{3}$ \\ ${ }^{1}$ Division of Fossil Primates, Duke University Lemur Center, Durham, North Carolina 27705, USA 〈gregg.gunnell@duke.edu〉 \\ ${ }^{2}$ Department of Earth and Atmospheric Sciences, University of Alberta, Edmonton, AB, T8N 7B2, Canada 〈zonnevel@ualberta.ca〉 \\ ${ }^{3}$ Department of Geological Sciences, Albion College, Albion, MI 49224, USA 〈wbartels@albion.edu〉
}

\begin{abstract}
Fieldwork conducted in the Wasatch Formation in and around Fossil Butte has yielded a diverse assemblage of early Eocene vertebrates. Fossil vertebrates are distributed through three discrete stratigraphic intervals within the uppermost $180 \mathrm{~m}$ of the main body of the Wasatch Formation underlying the Green River Formation. These assemblages were derived primarily from fluvial overbank mudstone units overprinted with variably well-developed paleosols. The lowest $(20 \mathrm{~m})$ and highest $(60 \mathrm{~m})$ sections are characterized by less mature and more hydromorphic paleosols, whereas the middle section $(100 \mathrm{~m})$ is typified by more mature paleosols and more abundant channel sandstones.

The combined assemblages contain at least 46 species of mammals. Faunal characteristics include high abundances of equid perissodactyls and a relatively high abundance and diversity of notharctines primates, an apparent absence of omomyid primates, relatively high rodent diversity, and relatively diverse and abundant artiodactyls. One new genus (Eoictops new genus) and three new species (Eoictops novaceki new species, Palaeosinopa lacus new species, and ?Notoparamys blochi new species) are included in the Fossil Butte assemblage. Also recorded are late occurrences of two hyopsodontid condylarths and an early occurrence of a rare phenacodontid condylarth. The relatively high abundances of equids and notharctines suggest that vertebrate samples were derived from relatively open paleohabitats that included forested areas along water courses.

All three assemblages contain characteristic Lysitean (Wasatchian biochron Wa-6) elements, but the occurrence of the palaeotheriid perissodactyl Lambdotherium in the uppermost horizon indicates a Lostcabinian (Wa-7) age for at least the top of the Wasatch Formation. The overlying predominantly fish-bearing Fossil Butte Member of the Green River Formation also contains Lambdotherium and is therefore Wa-7 in age as well.
\end{abstract}

\section{Introduction}

Fossil vertebrates from Fossil Butte National Monument (FBNM), Wyoming were first discovered in the mid-1800s (Leidy, 1856; Hayden, 1871). Thinly bedded micrite layers in the lacustrine Green River Formation in the central part of Fossil Basin have produced an amazing variety of fish, crocodylians, turtles, birds, rare mammals, and invertebrates (including ostracodes, decapods, gastropods, pelecypods, and insects) (Grande, 1984, 2001, 2013; Buchheim, 1994; Buchheim and Eugster, 1998; Buchheim et al., 2011). Despite numerous reports on the paleontology of aquatic vertebrate assemblages in the Green River Formation (particularly the fish; e.g., Leidy, 1856; Thorpe, 1938; Grande, 1984, 2013; Grande and Bemis, 1998), little attention has been given to fossils in the alluvial strata with which the lacustrine beds are interstratified.

This study documents the mammalian faunal assemblage of the Eocene Wasatch Formation in the area of Fossil Butte collected by a joint Albion College-University of MichiganUniversity of Alberta expedition in conjunction with Fossil Butte National Monument. These fossils are important as they provide insight into the ecology and environment of the lowlands adjacent to Fossil Lake during the early Eocene. Additionally, they provide well-defined age constraints on Eocene fluvial-lacustrine strata in Fossil Basin and firmly establish the middle to late early Eocene age (Wa-6-Wa-7) of the Wasatch Formation (Gingerich, 2001; Gunnell et al., 2009).

\section{Geologic setting}

Eocene strata at Fossil Butte National Monument were deposited in Fossil Basin, a small, north-south trending, structurally controlled sedimentary basin within the Wyoming Overthrust Belt (Fig. 1). Fossils mammals reported here were recovered from the uppermost $180 \mathrm{~m}$ of the main body of the Wasatch Formation (Fig. 2), which stratigraphically underlies the Fossil Butte Member of the Green River Formation (Oriel and Tracy, 1970). In Fossil Basin, the Wasatch Formation consists primarily of brightly variegated mudstone with subordinate interbedded siltstone, sandstone, and conglomerate (Hayden, 1869; Oriel and Tracy, 1970) and represents deposition on an intermontane alluvial plain (Oriel and Tracy, 1970; Zonneveld et al., 2006). 


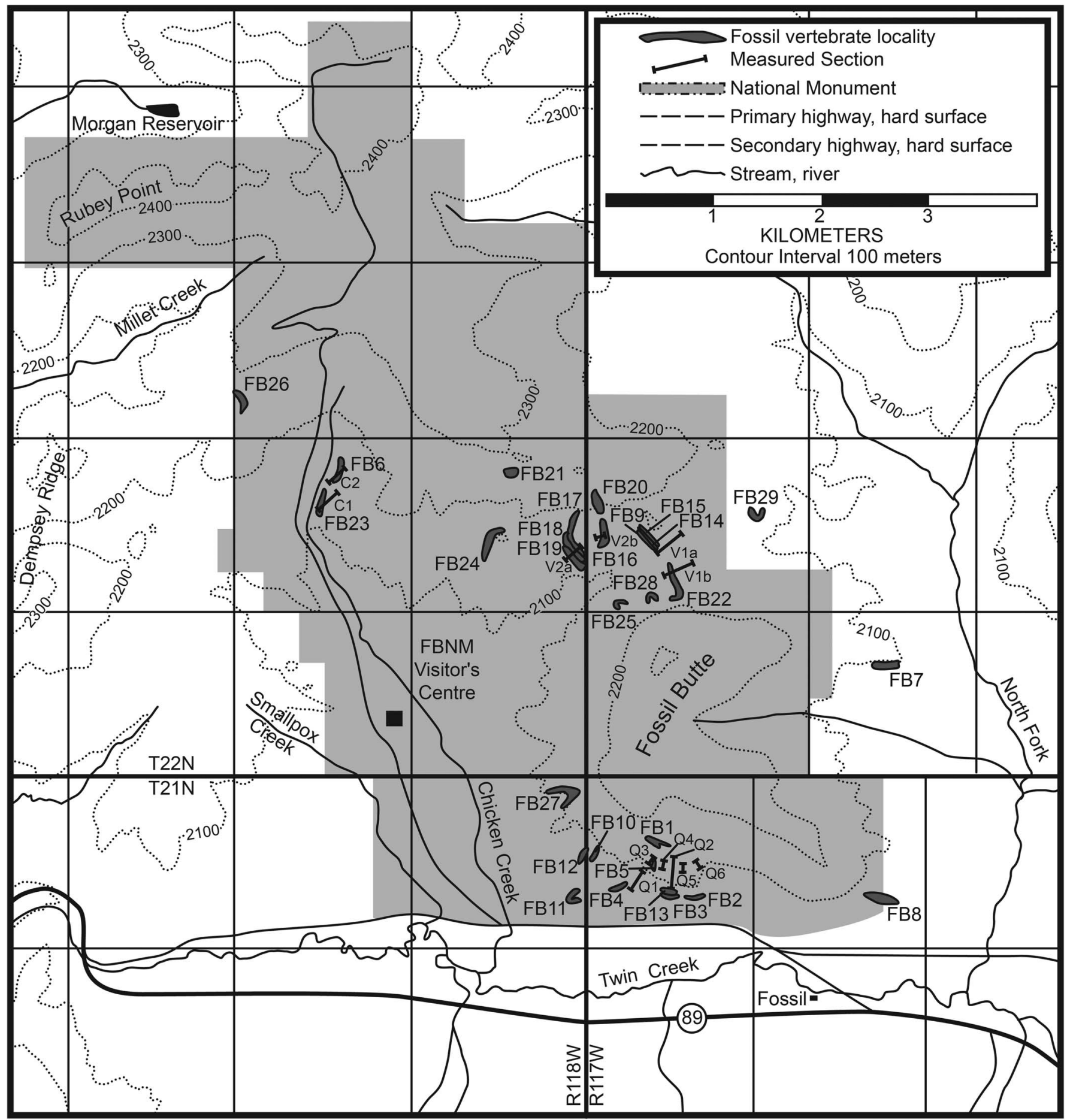

Figure 1. Map showing fossil vertebrate localities and measured sections in the Wasatch Formation at Fossil Butte National Monument, Lincoln County, southwestern Wyoming.

Distribution of vertebrate fossils in the Wasatch Formation.Eocene vertebrates are well known from Fossil Basin. Most of these fossils come from the Green River Formation (Grande, 1984, 2001, 2013); however, fossil vertebrates are also known from the Wasatch and Fowkes formations (Gazin, 1952, 1961, 1962; Nelson, 1973).

Within the Wasatch Formation at FBNM, vertebrate fossils are known only from the lower member, main body, and Bullpen

Figure 2. Composite measured sections at Fossil Butte National Monument and stratigraphic distribution of important Fossil Butte (FB) fossil localities. Sections were measured in the three main areas of Wasatch outcrop exposure: (1) near the historic quarry trail on the south face of Fossil Butte (Quarry); (2) through the valley on the north side of Fossil Butte (Valley Wall, Valley Center); and (3) near the head of Chicken Creek (arrow indicates position of Chicken Creek section below Valley section). General locations of composite sections are shown on Figure 1. 


\begin{tabular}{|c|c|}
\hline \\
\hline \multicolumn{2}{|c|}{$\begin{array}{l}\text { Lithology patterns } \\
\text {-mottled purple mudstone }\end{array}$} \\
\hline & -mottled red mudstone \\
\hline & -mottled yellow mudstone \\
\hline & -mottled green mudstone \\
\hline & -grey to mottled grey mudstone \\
\hline & -siltstone \\
\hline & $\begin{array}{l}\text {-very fine- to fine-grained } \\
\text { sandstone, tabular beds }\end{array}$ \\
\hline & $\begin{array}{l}\text {-cross-stratified fine- to } \\
\text { coarse-grained sandstone }\end{array}$ \\
\hline & -calcareous shale \\
\hline & -limestone \\
\hline$\because \because \because \vdots$ & -pebble lenses \\
\hline & $\begin{array}{l}\text {-calcium-carbonate } \\
\text { nodules }\end{array}$ \\
\hline
\end{tabular}

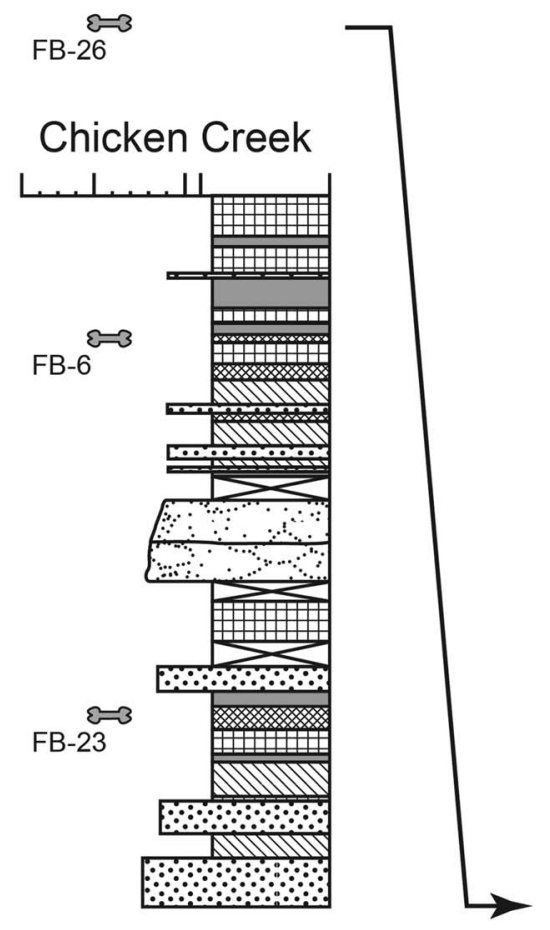

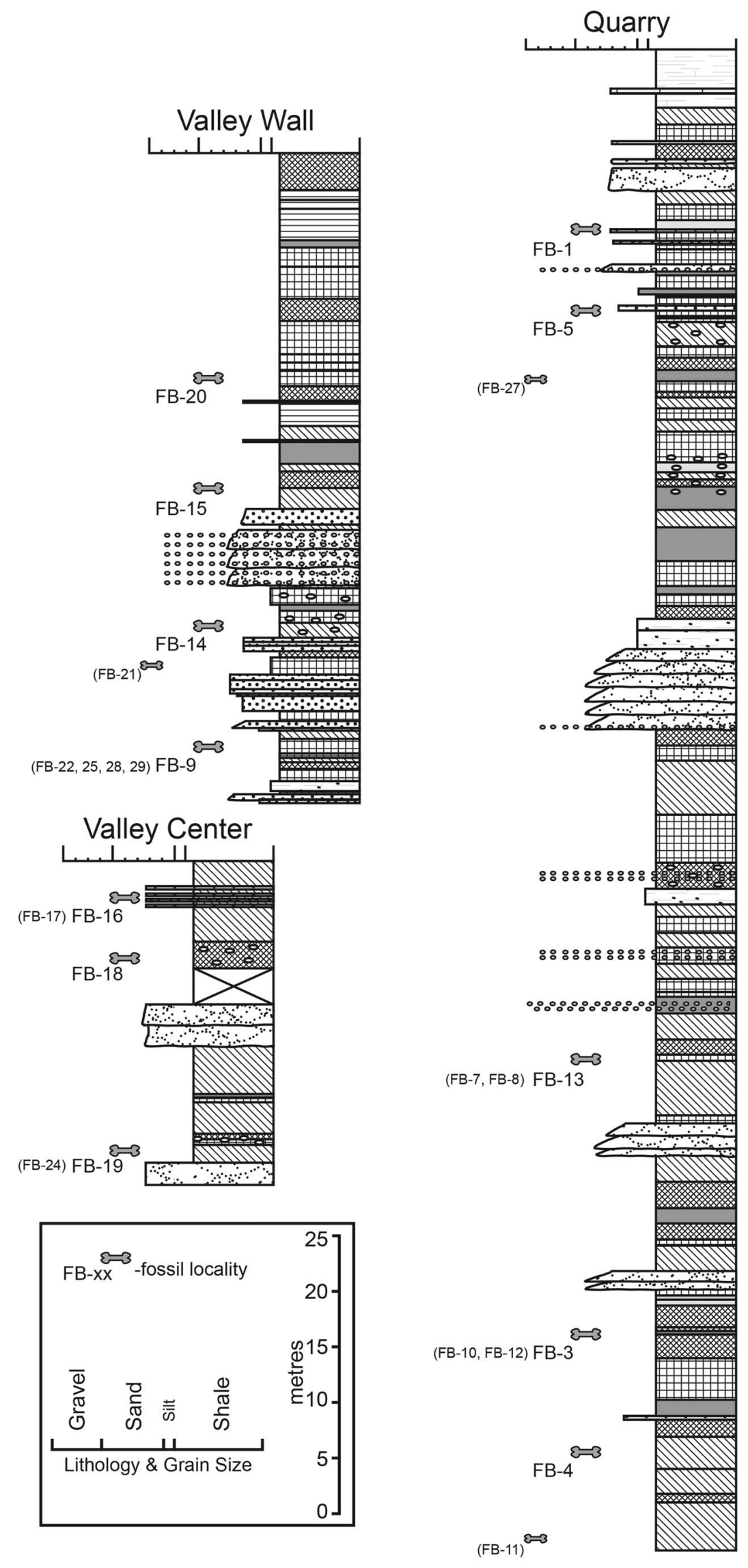


Member. A single tooth of the condylarth Meniscotherium $\mathrm{cf}$. $M$. robustum was collected from the lower member near the northwestern margin of the Monument. Fish bones and scales (Asineops and Lepisosteus), common in the Green River Formation, also occur in the lower and Bullpen members.

Fossil vertebrates are considerably more common in the main body of the Wasatch Formation in and around FBNM. Small faunal assemblages have been described from Knight Station (near Evanston), Elk Mountain ( $20 \mathrm{~km}$ south of FBNM) and from the Monument itself (Hayden, 1869; Cope, 1872, 1873; Gazin, 1952, 1961, 1962). Recent fieldwork at FBNM has resulted in a diverse collection of mammal fossils from 29 localities in the $180 \mathrm{~m}$ of the main body of the Wasatch Formation (Fig. 1, Table 1).

\section{Materials and methods}

Repositories and institutional abbreviations.-Most of the fossil materials described in this paper are housed and cataloged at storage facilities of the National Park Service, Fossil Butte National Monument, near Kemmerer, Wyoming, USA (FBF = old Fossil Butte catalog number; FOBU = new Fossil Butte catalog number). Those few specimens not housed at Fossil Butte can be found in the collections at the University of Michigan, Museum of Paleontology, Ann Arbor (UM); the United States National Museum, Smithsonian Institution, Washington, DC (USNM); or the Yale Peabody Museum of Natural History, Princeton Collection, Yale University, New Haven, Connecticut, USA (YPM-PU).

\section{Systematic paleontology}

Nomenclature abbreviations. $-\mathrm{Wa}=$ Wasatchian biochronologic zone; FB = Fossil Butte field number (for specimen references); FB = University of Michigan Fossil Butte field locality (for locality references). Lower teeth are indicated by a lowercase letter and tooth position number (e.g., $\mathrm{m} 1$ = lower first molar), upper teeth by an uppercase letter and tooth position number (e.g., P3 = upper third premolar). All measurements are provided in millimeters.

Class Mammalia Linnaeus, 1758

Order Didelphimorphia Gill, 1872

Family Didelphidae Gray, 1821

Tribe Didelphini Crochet, 1979

Genus Copedelphys Korth, 1994a

Type species.-Peratherium titanelix Matthew, 1903, Renova Formation, Montana.

Copedelphys innominata (Simpson, 1928)

Figure 3.1-3.2

\section{Peratherium innominatum Simpson, p. 6, fig. 5}

Holotype.-AMNH 11493, left dentary m1-4, Bridgerian biochron Br2, Bridger Formation, Millersville, Uinta County, Wyoming.
Table 1. Wasatch Formation mammalian faunal list - Fossil Butte National Monument.

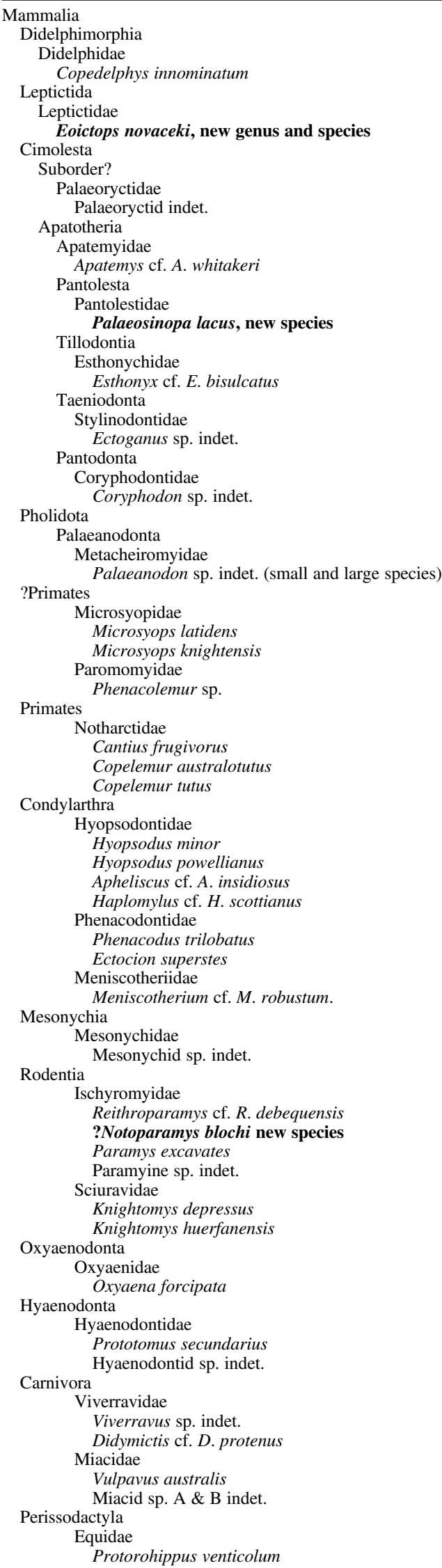


Table 1. (Continued)

\begin{tabular}{c}
\hline Xenicohippus craspedotum \\
Equid sp. indet. \\
Helaletidae \\
Heptodon calciculus \\
Palaeotheriidae \\
Lambdotherium popoagicum \\
Artiodactyla \\
Dichobunidae \\
Bunophorus grangeri \\
Diacodexis secans \\
Homacodontidae \\
Hexacodus uintensis \\
\hline
\end{tabular}

Occurrence.-Locality FB-19, late middle early Eocene, Wasatchian biochronologic zone Wa-6, main body, Wasatch Formation, Fossil Basin, Lincoln County, Wyoming.

Materials._FOBU 6338, left dentary p3-m2.

Remarks.-The referred specimen is in the size range of both Copedelphys innominatum and Peradectes chesteri. It differs from Peradectes in having a distinct lower molar entoconid and well-developed entoconid notch with a low hypoconulid. It also has $\mathrm{p} 3$ smaller than $\mathrm{m} 1$ and $\mathrm{m} 1$ with a widely open trigonid lingually. This combination of characters differentiates FOBU 6338 from both Peradectes and Herpetotherium (Korth, 2008).

Rothecker and Storer (1996) moved the species Peratherium innominatum, from Peratherium to Copedelphys based mostly on its very small size, upper molars with tiny conules and similar sized stylar cusps, and open lower molar trigonids, especially on $\mathrm{m} 1$. The specimen referred here is even smaller than those from Lac Pelletier described by Rothecker and Storer (1996), but the lower molars do have open trigonids lingually. This specimen could conceivably represent a new species of Copedelphys, but given the lack of any known upper molars at present a new name seems premature. Nonetheless this record represents one of the earlier known occurrences of this tiny marsupial outside of the seemingly anomalous earliest Wasatchian record at Castle Gardens in the Bighorn Basin (see Strait, 2001).

Measurements._FOBU 6338: $\mathrm{p} 3=1.29 \times 0.72, \mathrm{~m} 1=1.36 \mathrm{x}$ $0.79 ; \mathrm{m} 2=1.40 \times 0.89$

\section{Order Leptictida McKenna, 1975 \\ Family Leptictidae Gill, 1872 \\ Genus Eoictops new genus}

Type species.—Eoictops novaceki new species by monotypy.

Diagnosis.—As for type species by monotypy.

Etymology.-Eos, Greek for early or dawn and Ictops (= Leptictis), a common North American Oligocene leptictid genus, in reference to the earlier occurrence of a related species (and in keeping with Palaeictops, another related taxon, as proposed by Matthew, 1899).

Remarks.-Recognition of true Diacodon as an erinaceomorph (Novacek, 1982; Novacek et al., 1985) necessitates a new generic name for Fossil Butte a specimen once assigned to
Diacodon since it is clear (see below) that this specimen is a leptictid that differs from all previously known North American members of this order.

\section{Eoictops novaceki new species}

Figure 3.3-3.4

1952 Diacodon, cf. alticuspis; Gazin, p. 20

1962 Diacodon, cf. alticuspis; Gazin, p. 22

Holotype.-Type and only specimen, YPM-PU 16171, left dentary with $\mathrm{p} 5$ (erupting), $\mathrm{m} 1-2$, and broken $\mathrm{m} 3$, found "Three miles northwest of Fossil, Wyoming, Wasatch Formation, about 100 feet below the Green River Formation" Gazin, 1952, p. 20 (approximately equivalent to UM Localities FB-7, FB-8, FB-13, FB-19, and FB-24).

Diagnosis.-Differs from all other North American leptictids in having $\mathrm{p} 5$ the same length as $\mathrm{m} 1$ (other leptictids have $\mathrm{p} 5$ longer to much longer than $\mathrm{m} 1$ ), p5 with more trenchant talonid exhibiting a very reduced, anteriorly shifted and low entoconid connected via a postentocristid to a small hypoconulid that is appressed to the posterolingual aspect of the hypoconid, and $\mathrm{m} 3$ relatively smaller than other lower molars; further differs from Palaeictops by having relatively higher and anteriorly angled molar trigonids and relatively shorter molar talonids.

Occurrence.—Late middle early Eocene, Wasatchian biochronologic zone Wa-6, main body, Wasatch Formation, Fossil Basin, Lincoln County, Wyoming.

Description.- $\mathrm{p} 5$ is in its crypt, but the crown is fully formed. It had a prominent protoconid, the tip of which is now broken away. The p5 paraconid is robust, isolated from the anterior flank of the protoconid, centered on the tooth and positioned very low, forming the anterior base of the tooth. The metaconid appears as if it is somewhat smaller relative to the protoconid, but was probably nearly as tall and distinct. The protoconid and metaconid are positioned directly opposite each other and together form a high and prominent loph. The p5 talonid is trenchant and is dominated by a distinct and robust hypoconid that is placed just labial of center. A much lower and smaller entoconid is present as is a small hypoconulid. A weakly formed postcristid extends from the hypoconid to the hypoconulid and then continues as a curving postentocristid to reach the entoconid. The prehypocristid is steep and does not reach the postvallid, leaving the talonid open labially. Similarly, the preentocrisitd is absent, leaving the talonid open lingually through the entoconid notch. The talonid is shallowly basined due to the presence of the postcristid. There are no cingulids developed on $\mathrm{p} 5$.

The lower m1-2 of Eoictops novaceki n. sp. are nearly identical morphologically with $\mathrm{m} 2$ being only slightly smaller than $\mathrm{m} 1$. Both have tall and acute protoconids and metaconids with the metaconid being somewhat more robust than the protoconid and both being nearly equal height. These cusps are aligned labiolingually and are separated from each other by a fairly deep, v-shaped postprotocristid. The paraconid is much lower and relatively much smaller. It is placed just lingual of 
1

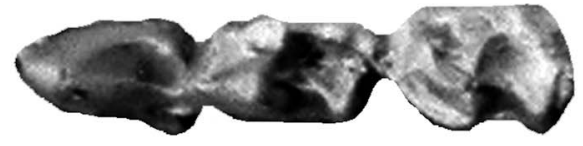

$2 \mathrm{~mm}$
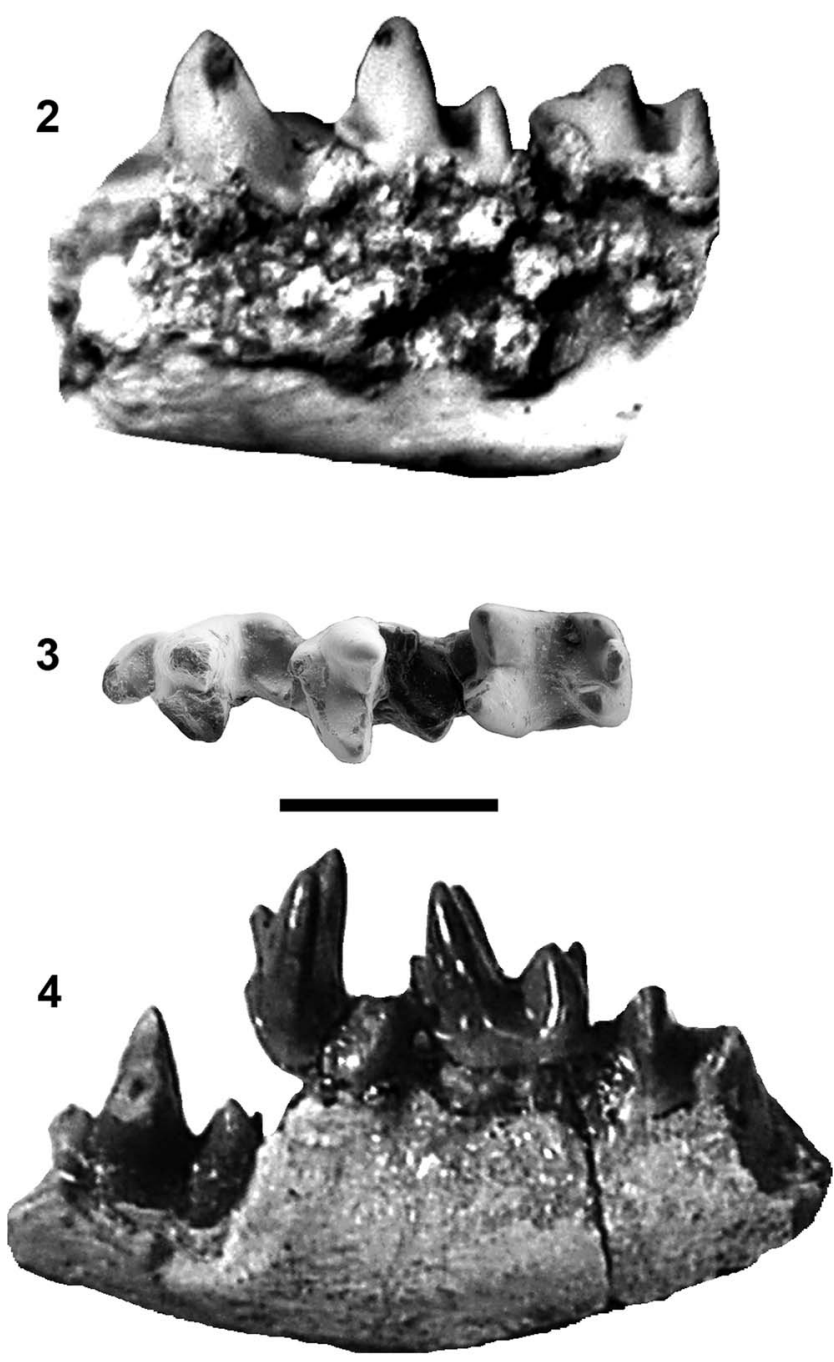

5

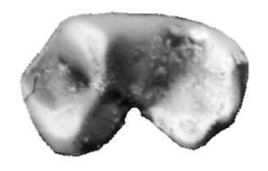

$1 \mathrm{~mm}$

6

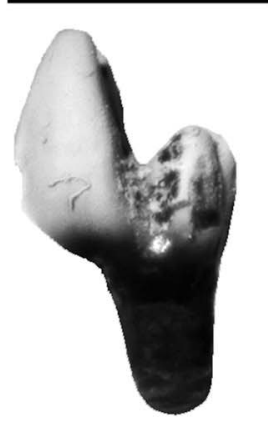

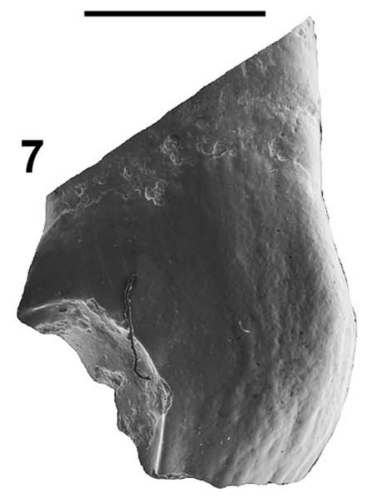

center on the prevallid, has an acute tip, and juts slightly anteriorly. A small precingulid is formed just labial and beneath the paraconid and constitutes the only cingulid developed on either tooth. Both teeth have high talonid cusps (not as high as the protoconid and metaconid, however) that are aligned in a slight arc along the posterior margin of the talonid. The hypoconid and hypoconulid are equally as tall and robust with the entoconid being only somewhat lower and smaller. Unlike $\mathrm{p} 5$, the prehypocristid extends to the base of the postvallid, joining that surface centrally and closing the talonid labially. The talonid is open lingually through a relatively broad entoconid notch. The talonid is narrowly basined with its occlusal surface sloping rather severely from labial to lingual (as it does in p5).

The lower third molar crown is damaged, but it is clear that $\mathrm{m} 3$ would have been smaller than either $\mathrm{m} 1$ or $\mathrm{m} 2$.

Etymology.-Specific name for Michael J. Novacek who untangled the confusing systematics of Cenozoic leptictids and additionally for his many contributions towards the understanding of early insectivorans and the origins of placental mammals.

Remarks.-Gazin $(1952,1962)$ noted the presence of a leptictid dentary from near Fossil Butte in the collections at Princeton University (now housed at the Yale Peabody Museum). He did not figure or describe this specimen in detail, but assigned it to Diacodon, cf. alticuspis. Novacek (1977) placed Diacodon, Gazin, 1952 in synonymy with Prodiacodon Matthew, 1929, although he did not specifically mention the Fossil Butte specimen under any of the synonymies he provided for Prodiacodon (also see Gunnell et al., 2008b). Novacek (1977) did specifically place Diacodon pineyensis Gazin, 1952 within Prodiacodon tauri-cinerei (Jepsen, 1930).

Following detailed analyses by Novacek (1982) and Novacek et al. (1985), Diacodon alticuspis is now recognized as an erinaceomorph (McKenna and Bell, 1997; Gunnell et al., 2008c). Gazin (1952) had previously stated that D. alticuspis was unlike other species of the genus in its p4 $(=\mathrm{p} 5)$ morphology, suggesting that perhaps Palaeictops should be resurrected to accommodate the species of Diacodon other than D. alticuspis (Gazin identified these specimens as Palaeictops in 1962). While Gazin (1952) assigned YPM-PU 16171 to Diacodon, cf. alticuspis, it is clear from his discussion that he viewed this specimen to be a leptictid.

While similar to Diacodon alticuspis in some ways (e.g., simpler $\mathrm{p} 5$ talonid, anteriorly sloping molar trigonids, especially notable on $\mathrm{m} 2$ ), YPM-PU 16171 is clearly distinguishable from this New Mexican taxon. Eoictops novaceki differs from Diacodon alticuspis in the following ways: (1) $\mathrm{m} 3$ smaller relative to m1-2 (m3 larger in D. alticuspis); (2) lower molar

Figure 3. Images 3 and 7 are SEM photographs; others are standard photographs. (1-2) FOBU 6338, Copedelphys innominatum, left dentary p3-m2 in occlusal (top) and lateral (bottom) views. (3-4) YPM-PU 16171, Eoictops novaceki $\mathrm{n}$. gen. n. sp. (Holotype), left dentary with $\mathrm{p} 5$ (erupting), m1-2, and broken $\mathrm{m} 3$ in occlusal (top, $\mathrm{m} 3$ not shown in this view) and lateral (bottom) views. (5-6) FOBU 6094, Palaeoryctid sp. indet., left broken $\mathrm{m} 1$ in occlusal (top) and buccal (bottom) views. (7) FOBU 6189, Apatemys cf. A. whitakeri, right I1 in lateral view. Scale bars $=2 \mathrm{~mm}$, except for images 5 and 6 where scale bars $=1 \mathrm{~mm}$. 
paraconids relatively higher, more cuspate and distinct (not lower, loph-like and less distinct); (3) p5 paraconid larger, higher, and more distinct; (4) p5 metaconid relatively larger and higher; and (5) p5 talonid more sloping (labially to lingually), less basined, and with a very tiny and low entoconid and a small hypoconulid that is positioned close to the posterior aspect of the hypoconid.

As Gazin noted (1952), YPM-PU 16171 has relatively high molar trigonids, which is one of the characters cited by Novacek (1977) distinguishing Prodiacodon from Palaeictops, but the differences in $\mathrm{p} 5$ structure cited above clearly differentiate this specimen from both Prodiacodon and Palaeictops.

Measurements.-YPM-PU 16171: $\mathrm{p} 5=3.0 \times 1.7, \mathrm{~m} 1=3.0 \mathrm{x}$ $2.1, \mathrm{~m} 2=2.8 \times 1.9$.

Order Cimolesta McKenna, 1975

Family Palaeoryctidae Winge, 1917

Palaeoryctid indet.

Figure 3.5-3.6

Occurrence.-Locality FB-16, late middle early Eocene, Wasatchian biochronologic zone Wa-6, main body, Wasatch Formation, Fossil Basin, Lincoln County, Wyoming.

Materials._FOBU 6094, left m1.

Remarks.-This slightly broken $\mathrm{m} 1$ represents a palaeoryctid based on its relatively high and compressed trigonid and low, lingually open talonid (Gunnell et al., 2008a). It differs from Eoryctes (Thewissen and Gingerich, 1989) in having a broader talonid basin that is open lingually and in having a more lingually placed entoconid. It differs from Palaeoryctes in having a less compressed trigonid with relatively larger and more inflated protoconid and metaconid, a more mesially directed and stronger paracristid, a relatively lower trigonid, and in having a small but distinct hypoconulid centered between the hypoconid and entoconid. This specimen differs from Pararyctes (Van Valen, 1966) in having a relatively higher trigonid, a less distinct entoconid, and in lacking an entocristid. It is similar to Ottoryctes (Bloch et al., 2004) in having a relatively broad talonid and may represent that genus, but definitive identification awaits better specimens.

\section{Measurements._FOBU 6094: $\mathrm{m} 1=2.4 \times 1.5$.}

Suborder Apatotheria Scott and Jepsen, 1936

Family Apatemyidae Matthew, 1909

Genus Apatemys Marsh, 1872

Type species.—Apatemys bellus Marsh, 1872, Bridger Formation, Henrys Fork, Wyoming.

Apatemys cf. A. whitakeri (Simpson, 1954)

Figure 3.7

1954 Teilhardella whitakeri Simpson, p. 1, fig. 1
Holotype.-AMNH 48004, left dentary p4-m2, Wasatchian Biochron Wa7, San Jose Formation, Almagre Facies, San Juan Basin, New Mexico.

Occurrence.-Locality FB-8, late middle early Eocene, Wasatchian biochronologic zone Wa-6, main body, Wasatch Formation, Fossil Basin, Lincoln County, Wyoming.

Materials.-FOBU 6189, right I1.

Remarks.-Apatemys is relatively rare in biochrons Wa-6 and Wa-7 (Gunnell et al., 2008a). A. whitakeri apparently is the only valid species of the genus now recognized from Wa-6 (Guthrie, 1967), therefore FB 96-093 is tentatively assigned to that taxon.

Suborder Pantolesta McKenna, 1975

Family Pantolestidae Cope, 1884

Genus Palaeosinopa Matthew, 1901

Type species.-Palaeosinopa veterrima Matthew, 1901, Willwood Formation, Bighorn Basin, Wyoming.

Palaeosinopa lacus new species

Figure 4.1-4.3

Holotype.-FOBU 6205, left dentary p2-m1, only known specimen, from Locality FB-5.

Diagnosis.—Differs from all other species of Palaeosinopa in having a very broad and bulbous $\mathrm{P} / 4$ with a basined talonid possessing small but distinct hypoconid and entoconid cusps. Further differs from other species of Palaeosinopa in having a relatively smaller (but still distinct) mental foramen placed beneath $\mathrm{p} 4$ rather than a larger foramen beneath $\mathrm{m} 1$. Palaeosinopa lacus $\mathrm{n}$. sp. is intermediate in size between Palaeosinopa lutreola and Palaeosinopa didelphoides $(?=$ Palaeosinopa veterrima $)$, being larger (about 25\%) than the former and smaller (about 30\%) than the latter.

Occurrence.-Late middle early Eocene, Wasatchian biochronologic zone Wa-6, main body, Wasatch Formation, Fossil Basin, Lincoln County, Wyoming.

Description.-The $\mathrm{p} 2$ is broken, preserving only its posteriormost part. This tooth is long and relatively narrow and has a tiny, centered talonid cuspule. The talonid is very short and narrow. Compared to P. didelphoides, the $\mathrm{p} 2$ of $P$. lacus is more elongate.

The p3 is broken posteriorly. It has no paraconid or metaconid and lacks an anterior basal cuspule (unlike $P$. didelphoides). The $\mathrm{p} 3$ paracristid is weakly defined and curves antero-lingually. The postvallid is flat and lacks a central ridge unlike $P$. didelphoides. Overall, $\mathrm{p} 3$ is relatively robust and heavily constructed with a blunt, rounded protoconid.

The $\mathrm{p} 4$ is broken anteriorly, so the disposition of the paraconid and paracristid cannot be determined. The protoconid is bulbous and robust with a flattened postvallid (lacking the central ridge present in $P$. didelphoides). There is no metaconid developed. The buccal and lingual margins of the postvallid are 
1

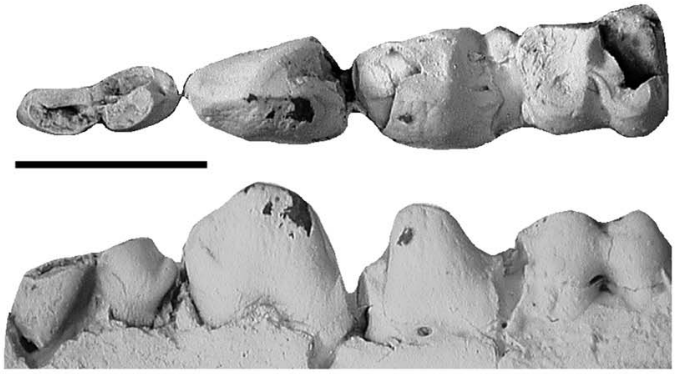

2

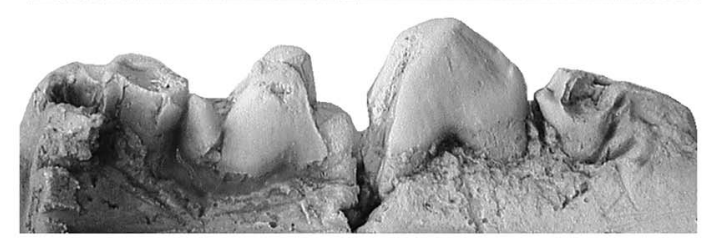

4
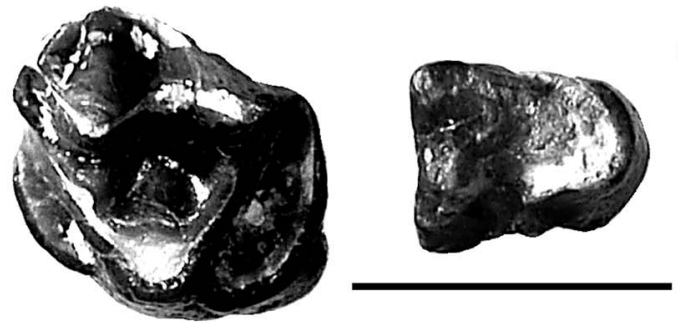

6
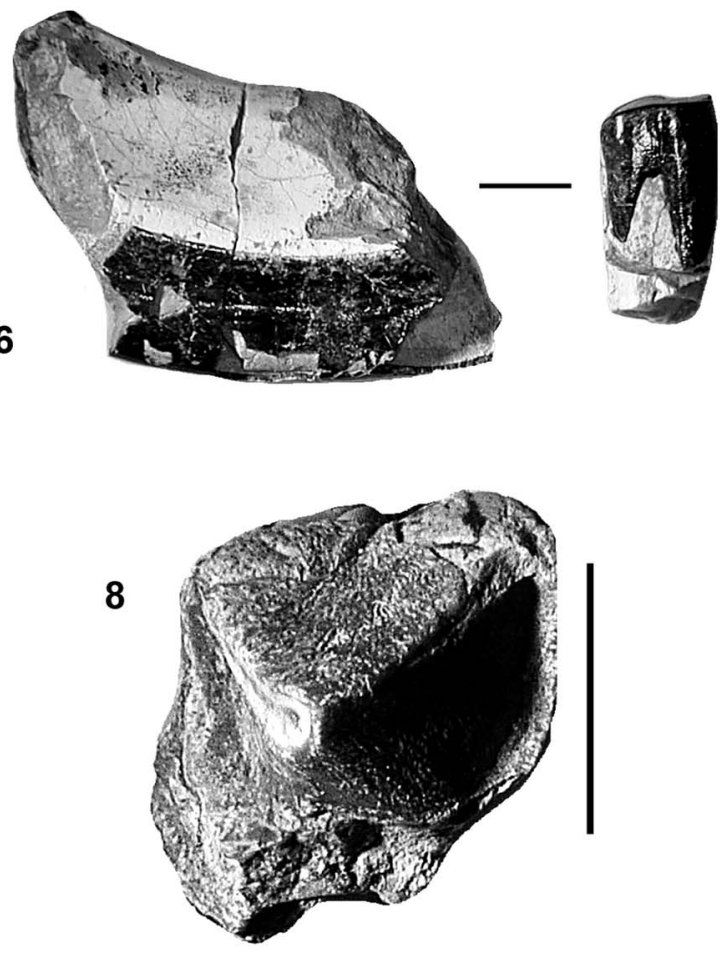

9

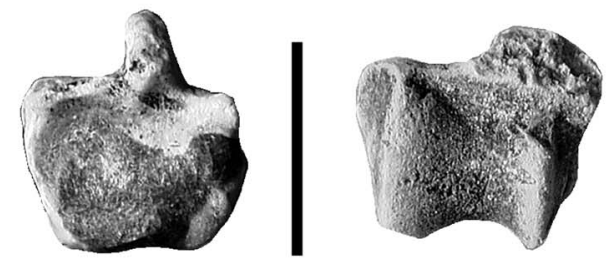

more vertical and less flared and sloping compared to P. didelphoides. Overall, $\mathrm{p} 4$ has a short and broad talonid with small, but distinct, hypoconid and entoconid cusps, the latter being slightly larger. There is a small basined area developed between these two cusps and the postvallid. Like all of the premolars of $P$. lacus, 44 lacks cingulid development.

The enlarged $\mathrm{p} 4$ of $P$. lacus is superficially similar to those seen in Paleocene pentacodontines (Gunnell et al., 2008a), but it differs from these taxa in being relatively less bulbous and enlarged, in lacking a metaconid, and in having a shorter, less well-developed talonid basin.

The lower first molar is somewhat broken and worn. It differs from other species of Palaeosinopa in having the talonid distinctly broader than the trigonid. The cristid obliqua joins the postvallid centrally as in most other Palaeosinopa species, but unlike the other species, nearly reaches the crest of the postvallid. The trigonid is worn into a flat triangle, the typical wear pattern exhibited by many pantolestids.

The dentary of $P$. lacus lacks the enlarged mental foramen beneath $\mathrm{m} 1$ typical of many pantolestids, instead having a relatively small mental foramen placed under the $\mathrm{p} 4$. The dentary, as in most pantolestids, is relatively shallow and tapers anteriorly.

Etymology.-Specific name from "lacus", Latin for lake, in reference to Fossil Lake, the shores of which provided the habitat for the mammals from Fossil Butte.

Remarks.-Matthew $(1909,1918)$ recognized three (perhaps four) species of Palaeosinopa and five species of Pantolestes. Gazin (1962) named an additional early Eocene pantolestid, Amaramnis (based on a single lower jaw with m2-3). While all three genera are probably valid, it seems nearly certain that there were fewer species present than have been previously recognized (Rose, 2006; Gunnell et al., 2008a). Matthew (1918) hinted at this when he tentatively suggested that Palaeosinopa didelphoides and $P$. veterrima may be conspecific. Further work is required to sort out the diversity of North American Eocene pantolestids.

Measurements.-FOBU 6205: $\mathrm{p} 2=4.2 \times 1.7, \mathrm{p} 3=4.4 \times 2.6$, $\mathrm{p} 4=4.6 \times 3.2, \mathrm{~m} 1=3.9 \times 3.3$.

Suborder Tillodontia Marsh, 1875

Family Esthonychidae Cope, 1883

Genus Esthonyx Cope, 1874

Type species.—Esthonyx bisulcatus Cope, 1874, San Jose Formation, New Mexico.

Figure 4. (1-3) FOBU 6205, Palaeosinopa lacus n. sp. (Holotype), left dentary with roots of $\mathrm{p} 2$ and slightly broken $\mathrm{p} 3-\mathrm{m} 1$ in occlusal (top), lateral (middle) and medial (bottom) views. (4) UM 102585, Esthonyx cf. E. bisulcatus, left Mx (labial portion missing) in occlusal view. (5) FOBU 6389, Esthonyx cf. E. bisulcatus, right $\mathrm{mx}$ trigonid in occlusal view. (6-7) FOBU 6361, Ectoganus sp. indet., incisor fragment (left) and isolated molar (right) in lateral views. (8) FOBU 6356, Coryphodon sp. indet., upper molar fragment in occlusal view. (9) FOBU 6097, Palaeanodon sp. indet., right distal radius in distal view. (10) FOBU 6198, Palaeanodon sp. indet., left broken astragalus in dorsal view. Scale bars $=5 \mathrm{~mm}$ for images $1-5$ and $9-10 ; 1 \mathrm{~cm}$ for images $6-8$. 
Esthonyx cf. E. bisulcatus Cope, 1874

Figure 4.4-4.5

1874 Esthonyx bisulcatus Cope, p. 6

Holotype.-USNM 1103, left dentary p3, m1-3, from Arroyo Blanco, Wasatchian Biochron Wa7, San Juan Basin, New Mexico.

Occurrence.-Localities FB-6, 7, 16, 19, late middle early Eocene, Wasatchian biochronologic zone Wa-6, main body, Wasatch Formation, Fossil Basin, Lincoln County, Wyoming.

Materials.-FB-6: FOBU 6190, left p4 trigonid; FB-7: UM 102585, left Mx fragment; UM 108144, left m1-2 (broken). FB-16: FOBU 6419, right mx fragment. FB-19: FOBU 6389, right $\mathrm{mx}$ trigonid.

Remarks.-These fragmentary teeth confirm the presence of Esthonyx at Fossil Butte. Estimating tooth size from the fragments preserved indicates that these specimens are in the size range of E. bisulcatus and probably represent that species.

Measurements.-All of these teeth are too broken to provide accurate measurements.

Suborder Taeniodonta Cope, 1876

Family Stylinodontidae Marsh, 1875

Genus Ectoganus Cope, 1874

Type species.-Ectoganus gliriformis Cope, 1874, San Jose Formation, New Mexico.

Ectoganus sp. indet.

Figure 4.6-4.7

1962 Ectoganus sp. Gazin, p. 44, Pl. 12, fig. 7

Occurrence.-Locality FB-16, late middle early Eocene, Wasatchian biochronone Wa-6, main body, Wasatch Formation, Fossil Basin, Lincoln County, Wyoming.

Materials._FOBU 6361, incisor and molar fragments.

Remarks.-While fragmentary, this specimen confirms the presence of Ectoganus in the Fossil Butte sample.

Measurements.-FOBU 6361 is too fragmentary to be certain of tooth position or to provide accurate measurements. Gazin (1962) figured three fragmentary teeth (USNM 22785) of Ectoganus sp. from Fossil Butte.

Suborder Pantodonta Cope, 1873

Family Coryphodontidae Marsh, 1876

Genus Coryphodon Owen, 1845

Type species.-Coryphodon eocanus Owen, 1845, London Clay, Essex, United Kingdom.

\section{Coryphodon sp. indet.}

Figure 4.8
1952 Coryphodon, cf. radians (in part); Gazin, p. 63, Pl. 9

1962 Coryphodon radians (in part); Gazin, p. 70, Pl. 11, figs. $1-5$, Pl. 12, figs. 1-2

Occurrence.-Localities FB-6, 7, 9-12, 18, late middle early Eocene, Wasatchian biochronologic zone Wa-6, main body, Wasatch Formation, Fossil Basin, Lincoln County, Wyoming.

Materials.-FB-6: FOBU 6135, associated teeth and tooth fragments; FB 96-014, canine. FB-7: UM 102582, tooth fragments; UM 102586, tooth fragments; UM 102592, tooth fragments. FB-9: FB 96-062, canine; FB 96-067, tooth fragments; FB 96-068, canine; FB 97-023, tooth fragments. FB-10: FB 96-082, canine fragments. FB-11: FOBU 6356, upper molar fragment; FOBU 6363, tooth fragments; FB 96-086, postcrania; FB 96-088, tooth fragments. FB-12: FB 96-091, ulna. FB-18: FOBU 6286, postcrania.

Remarks.-There are two species of Coryphodon recognized from Wa-6 in Wyoming (Uhen and Gingerich, 1995), the larger C. lobatus and the smaller $C$. armatus. Most of the Fossil Butte Coryphodon specimens are too fragmentary to assign to either of these species. The relatively large size of the one measurable specimen, FOBU 6135, indicates that this individual probably represents Coryphodon lobatus. In a table (p. 9) published in 1952, Gazin indicated that Coryphodon sp. was present at Fossil Butte, but he did not mention any specific specimens in his discussion (Gazin, 1952, p. 63). Gazin (1962, p. 70) noted the presence of scattered, fragmentary remains of Coryphodon from the lower slopes at Fossil Butte and included these specimens under his discussion of Coryphodon radians, a taxon now recognized as being restricted to Wasatchian biochron Wa-3 (Uhen and Gingerich, 1995).

Measurements._FOBU 6135: $\mathrm{p} 4=26.1 \times 20.8$.

Order Pholidota Weber, 1904

Suborder Palaeanodonta Matthew, 1918

Family Metacheiromyidae Wortman, 1903

Genus Palaeanodon Matthew, 1918

Type species.-Palaeanodon ignavus Matthew, 1918, Willwood Formation, Wyoming.

Palaeanodon sp. indet.

Figure 4.9-4.10

Occurrence.-Localities FB-1, 9, 19, late middle early Eocene, Wasatchian biochronologic zone Wa-6 (FB-9, 19) and late early Eocene, Wasatchian biochronologic zone Wa-7 (FB-1), main body, Wasatch Formation, Fossil Basin, Lincoln County, Wyoming.

Materials.-FB-1: FOBU 6163, right metacarpal II fragment; FOBU 6198, left astragalus. FB-9: FOBU 6097, right distal radius. FB-19: FOBU 6315, right dentary. 
Remarks.-There are two different sizes of palaeanodonts present at Fossil Butte. The small sample size and fragmentary nature of the remains preclude specific determinations.

Order ?Primates Linnaeus, 1758

Suborder Plesiadapiformes Simons and Tattersall in Simons, 1972

Superfamily Microsyopoidea Osborn and Wortman, 1892

Family Microsyopidae Osborn and Wortman, 1892

Genus Microsyops Leidy, 1872

Type species.-Limnotherium elegans Marsh, 1871, Bridger Formation, Wyoming.

\section{Microsyops latidens (Cope, 1882a)}

Figure 5.1-5.2

1882a Cynodontomys latidens Cope, p. 151

Holotype.-AMNH 4195, left dentary p4, right dentary m1-2, from Wasatchian Biochron Wa6, Bighorn Basin, Wyoming.

Occurrence.-Localities FB-9, 16, 18, late middle early Eocene, Wasatchian biochronologic zone Wa-6, main body, Wasatch Formation, Fossil Basin, Lincoln County, Wyoming.

Materials.-FB-9: FB 97-020, left m1; FB-16: FOBU 6281, left dentary m1-2 talonids; FOBU 6366, left dentary m1-m/2 talonid. FB-18: FOBU 6287, left dentary m2-3.

Remarks.-Microsyops latidens is the most common species of Microsyops from Wa-6 (Gunnell, 1989). All of these specimens fall in the size range of $M$. latidens.

Measurements.-FOBU 6366: $\mathrm{m} 1=3.4$ x 2.6; FOBU 6287: $\mathrm{m} 2=3.2 \times 2.5, \mathrm{~m} 3=3.7 \times 2.4$.

\section{Microsyops knightensis (Gazin, 1952)}

1952 Cynodontomys knightensis Gazin, p. 20, Pl. 2, fig. 1

Holotype.-USNM 19314, left dentary p4-m3, from Knight Beds (= Wasatch Formation), LaBarge Fauna, Green River Basin, Wyoming.

Occurrence.-Locality FB-16, late middle early Eocene, Wasatchian biochronologic zone Wa-6, main body, Wasatch Formation, Fossil Basin, Lincoln County, Wyoming.

Materials.-FOBU 6199, left dentary m1-3 (teeth fragmentary; includes associated miscellaneous fragments cataloged as FOBU 6198).

Figure 5. (1) FOBU 6366, Microsyops latidens, left dentary $\mathrm{m} 1$ in occlusal view. (2) FOBU 6287, Microsyops latidens, left dentary m2-3 in occlusal view. (3) FOBU 10011, Phenacolemur sp., left I1 in postero-occlusal view. (4) FOBU 6362, Cantius frugivorus, right dentary m2-3 in occlusal view. (5) UM 102587 , Copelemur australotutus, right dentary p4-m3 in occlusal view. (6) FOBU 6193, Copelemur tutus, right dentary with $\mathrm{p} 3$ talonid, $\mathrm{p} 4-\mathrm{m} 1$, and partial trigonid of $\mathrm{m} 2$ showing distinct paraconid in occlusal view. Scale bars $=5 \mathrm{~mm}$ for images $1-2$ and $4-6 ; 2 \mathrm{~mm}$ for image 3 .
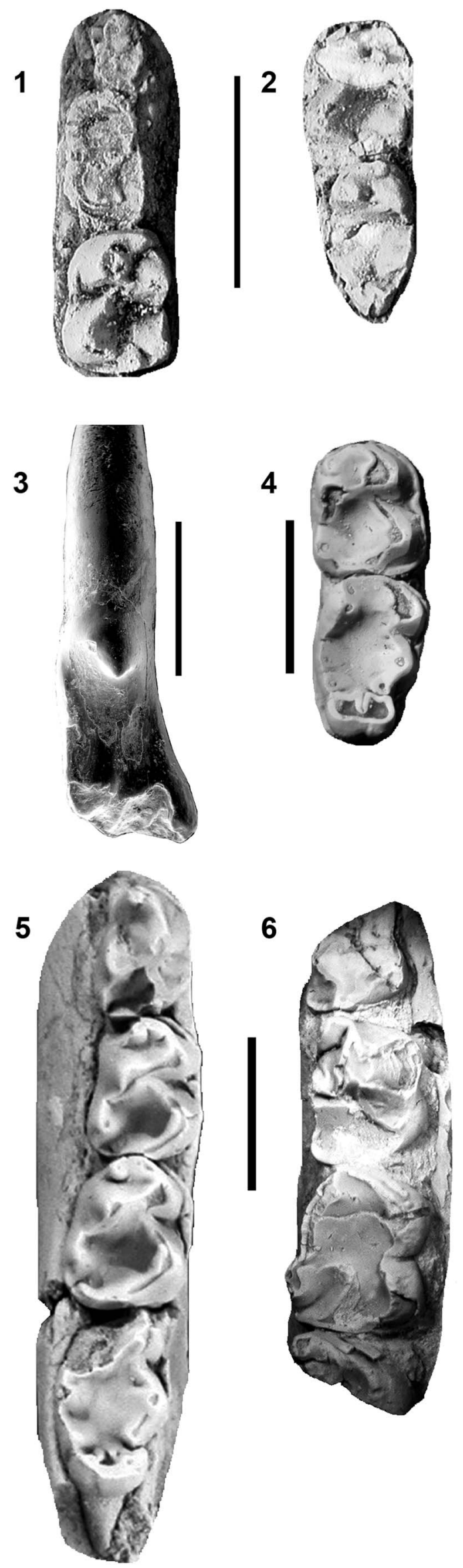
Remarks.-This single specimen represents a species of Microsyops larger than M. latidens. It can be identified as the common Wa-7 species of Microsyops-M. knightensis. As such, it represents the earliest known (Lysitean = Wa6) occurrence of this species.

\section{Measurements._FOBU 6199: $\mathrm{m} 2=4.2 \times 3.3$.}

Superfamily Paromomyoidea Simpson, 1940

Family Paromomyidae Simpson, 1940

Genus Phenacolemur Matthew, 1915b

Type species.-Phenacolemur praecox Matthew, 1915b, Willwood Formation, Wyoming.

\section{Phenacolemur sp.}

Figure 5.3

Occurrence.-Horizon equivalent to locality FB-11 late middle early Eocene, Wasatchian biochronologic zone Wa-6, main body, Wasatch Formation, Fossil Basin, Lincoln County, Wyoming.

Materials._FOBU 10011, left I1.

Remarks.-There is a single specimen representing Phenacolemur from Fossil Butte. It is not currently possible to identify this isolated upper incisor to the species level.

Order Primates Linnaeus, 1758

Infraorder Adapiformes Szalay and Delson, 1979

Family Notharctidae Trouessart, 1879

Subfamily Notharctinae Trouessart, 1879

Genus Cantius Simons, 1962

Type species.-Protoadapis eppsi Cooper, 1932, Blackheath beds, Abbey Wood, Woolwich, Kent, United Kingdom.

Cantius frugivorus (Cope, 1875)

Figure 5.4

1875 Pelycodus frugivorus Cope, p. 14

1962 Pelycodus, near P. jarrovii; Gazin, p. 28

Holotype.-Unnumbered (specimen now lost), right dentary m2-3, from San Jose Formation, San Juan Basin, New Mexico (Neotype designated by Beard, 1988: CM 37448, right dentary p3-m3, CM Almagre Locality 2, Sandoval County, New Mexico).

Occurrence--Localities FB-1, 4, 6, 7, 11, 19, 25, 26, late middle early Eocene, Wasatchian biochronologic zone Wa-6 (FB-4, 6-7, 11, 19, 25-26) and late early Eocene, Wasatchian biochronologic zone Wa-7 (FB-1), main body, Wasatch Formation, Fossil Basin, Lincoln County, Wyoming.

Materials.-FB-1: FB 95-002, right $\mathrm{m} 2$ trigonid; FB 96-048, right m2; FB 97-006, navicular. FB-4: FOBU 6362, right dentary p4, m2-3; FOBU 9864, right maxilla M3. FB-6: FB 97-062, right M2. FB-7: UM 102588, right dentary m2, left m1. FB-11: FOBU
6373, left dentary m2-3; FOBU 6381, right dentary m2-3; FOBU 6391, right dentary p4-m3; FOBU 9895, left dentary p4-m2. FB-19: FOBU 6114, right dentary m3. FB-25: FOBU 6116, right dentary p3-m3. FB-26: FOBU 6112, right dentary m2-3.

Remarks.-Cantius frugivorus is the most common species of Wa-6 adapiform known from southern Wyoming (Gunnell, 2002). These referred specimens agree in size and morphology with that species. Gazin (1962, p 28) noted the presence of five adapiform specimens in the USNM collections from the "slopes of Fossil Butte" (including USNM 22259) that are larger than "Pelycodus" trigonodus. One of these specimens (USNM 22261) is the holotype of Copelemur australotutus (see below), while the others likely represent Cantius frugivorus.

Measurements.-FOBU 6362: $\mathrm{p} 4=3.9 \times 2.7, \mathrm{~m} 2=4.2 \times 3.7$, $\mathrm{m} 3=5.1 \times 3.4$; FOBU 6373: $\mathrm{m} 2=4.0 \times 3.5$; FOBU 6381: $\mathrm{m} 2=4.6 \times 4.2, \mathrm{~m} 3=6.8 \times 3.7 ;$ FOBU 6391: $\mathrm{m} 3=5.2 \times 3.5$; FB 96-048: $\mathrm{m} 2=4.5 \times 3.6$; FOBU 6114: $\mathrm{m} 3=5.4 \times 3.3$; FOBU $6116: \mathrm{p} 3=3.5 \times 2.5, \mathrm{p} 4=3.8 \times 3.0, \mathrm{~m} 1=4.1 \times 3.6, \mathrm{~m} 2=4.3 \times 3.8$; FOBU 6112: $\mathrm{m} 3=5.5$ x 3.4; UM 102588: $\mathrm{m} 2=4.4$ x 4.1 .

Genus Copelemur Gingerich and Simons, 1977

Type species.-Tomitherium tutum Cope, 1877, San Jose Formation, New Mexico.

Copelemur australotutus Beard, 1988

Figure 5.5

Holotype.-USNM 22261, left dentary p3-m1, from north face of Fossil Butte, Wasatch Formation, Fossil Basin, Wyoming.

Occurrence.-Localities FB-1, 7, 8, 11, 19, 21, late middle early Eocene, Wasatchian biochronologic zone Wa-6 (FB-7-8, $11,19,21)$ and late early Eocene, Wasatchian biochronologic zone Wa-7 (FB-1), main body, Wasatch Formation, Fossil Basin, Lincoln County, Wyoming.

Materials._FB-1: FB 96-042, left m3 (enamel eroded); FB 96-096, right $\mathrm{m} 1$ fragment. FB-7: UM 102587, right dentary p4-m3; UM 102589, left maxilla M2-3, C1, right dentary m3; UM 108138, left m1. FB-8: FB 96-026, left $\mathrm{m} 1$ trigonid. FB-11: FOBU 9893, right dentary m1-2. FB-19: FB 97-089, left dentary m2. FB-21: FBF 150, right dentary m2-3.

Remarks.-Beard (1988) named C. australotutus based on a relatively poorly preserved specimen from Fossil Butte (USNM 22261). These newly referred specimens corroborate Beard's recognition of $C$. australotutus as a distinct species of Copelemur. Relatively large samples of $C$. australotutus from the Washakie Basin (Gunnell, 2002), in combination with those from Fossil Butte, make C. australotutus the best-known species of the genus.

Measurements.-FB 97-089: $\mathrm{m} 2=4.5$ x 3.7; UM 102587: $\mathrm{p} 4=4.1 \times 3.0, \mathrm{~m} 1=4.5 \times 3.6, \mathrm{~m} 2=4.8 \times 4.0 ; \mathrm{UM} 102589$ : $\mathrm{M} 2=4.6 \times 6.4, \mathrm{M} 3=4.8 \times 5.7, \mathrm{~m} 3=6.0 \times 4.0$. 


\section{Copelemur tutus (Cope, 1877)}

Figure 5.6

1877 Tomitherium tutum Cope, p. 141, Pl. 39, fig. 19

1881 Pelycodus tutus (in part); Cope, p. 187

1915b Pelycodus tutus; Matthew, p. 441, fig. 15

1962 Pelycodus? tutus; Gazin, p. 29

1977 Copelemur tutus; Gingerich and Simons, p. 271, Pl. 1, fig. 3, text fig. 6b

1988 Copelemur tutus; Beard, p 454, Fig. 8, 9

Holotype.-Unnumbered (specimen now lost), right dentary p3-m1, from San Jose Formation, San Juan Basin, New Mexico (Neotype designated by Beard, 1988: UALP 10233, right dentary p3-m2, UALP Locality 7745, Regina Member, Sandoval County, New Mexico).

Occurrence.-Locality FB-13, late middle early Eocene, Wasatchian biochronologic zone Wa-6, main body, Wasatch Formation, Fossil Basin, Lincoln County, Wyoming.

Materials.-FOBU 6193, right dentary p4-m1.

Remarks.-Copelemur tutus is relatively common in the San Juan Basin in New Mexico but is rare from southern Wyoming (Gingerich and Simons, 1977; Gunnell, 2002). While this specimen is somewhat worn and broken, the clear presence of a distinct paraconid on $\mathrm{m} 2$, the presence of a short, lingually bowed entocristid and entoconid notch on $\mathrm{m} 1$, and the presence of a distinct, high metaconid and a strong paracristid on $\mathrm{p} 4$ identify it as Copelemur. Its large size confirms its identification as $C$. tutus.

Measurements.-FOBU 6193: p4 $=5.0 \times 3.8, \mathrm{~m} 1=5.6 \times 4.0$.

Order Condylarthra Cope, 1881

Family Hyopsodontidae Trouessart, 1879

Genus Hyopsodus Leidy, 1870

Type species.-Hyopsodus paulus Leidy, 1870, Bridger Formation, Wyoming.

\section{Hyopsodus minor Loomis, 1905}

Figure 6.1-6.2

1962 Hyopsodus, cf. H. miticulus (in part); Gazin p. 63

Holotype.-AC 3492, right dentary m1-3, from Wasatchian Biochron Wa6, Wind River Formation, Wind River Basin, Wyoming.
Occurrence.-Localities FB-4, 5, 6, 7, 9, 10, 15, 16, 18, 19 , 24-27, late middle early Eocene, Wasatchian biochronologic zone Wa-6, main body, Wasatch Formation, Fossil Basin, Lincoln County, Wyoming.

Materials.-FB-4: FOBU 6370, left maxilla M1-2; FOBU 6412, left dentary m1-2; FOBU 6434, right mx fragment. FB-5: FB 97-015, right P3. FB-6: FB 96-006, right dentary m2-3; FB 96-013, left mx talonid. FB-7: UM 102594, right M2. FB-9: FB 96-063, right dentary m2-3; FOBU 6213, left dentary m1-3. FB-10: FB 96-078, right m1. FB-15: FB 97-026, left maxilla P4-M1; FB 97-028, right dentary m1-3; FB 97-068, left dentary p4. FB-16: FB 97-033, right $\mathrm{m} 3$; FOBU 6392, left maxilla M1-2. FB-18: FB 97-075, right M2; FB 97-076, right dentary p4-m1; FB 97-081, right m2. FB-19: FB 97-095, right dentary m3; FB 97-099, left M2. FB-24: FB 97-108, right dentary m1-3. FB-25: FB 97-110, left M2. FB-26: FB 97-115, right dentary m2-3. FB-27: FOBU 6398, left M2.

Remarks.-These specimens are consistent in size and morphology with the relatively small species of Hyopsodus, $H$. minor, documented from several areas in the Green River Basin (Gazin, 1968), other areas in Wyoming, the San Juan Basin in New Mexico, and the Piceance Basin in Colorado (Redline, 1997). Gazin tentatively referred several specimens in the USNM collections from Fossil Butte (numbers not cited) to a relatively small species of Hyopsodus, H. miticulus but it is more likely, given the size of these specimens, that they represent $H$. minor instead.

Measurements.-FOBU 6370: $\mathrm{M} 1=3.1 \times 3.8, \mathrm{M} 2=3.2 \times 4.4$; FOBU 6398: $\mathrm{M} 2=3.6 \times 5.0$; FOBU 6412: $\mathrm{m} 1=3.2 \times 2.5$, $\mathrm{m} 2=3.3 \times 2.7 ;$ FOBU 6392: $\mathrm{M} 1=3.4 \times 4.3, \mathrm{M} 2=3.6 \times 4.7$; FB 96-063: $\mathrm{m} 2=3.5 \times 3.1, \mathrm{~m} 3=3.6$ x 2.7; FB 96-078: $\mathrm{m} 1=3.2 \times 2.6 ;$ FOBU 6213: $\mathrm{m} 1=3.2 \times 2.7, \mathrm{~m} 2=3.5 \times 3.0$, $\mathrm{m} 3=3.7 \times 2.8 ; \mathrm{FB} 97-026: \mathrm{P} 4=3.3 \times 4.3$, M1 = 3.7 x 4.9; FB 97-033: $\mathrm{m} 3=3.9 \times 2.6$; FB 97-068: $\mathrm{p} 4=3.8 \times 2.6$; FB 97-076: p4 =3.1 x 2.8, $\mathrm{m} 1=3.5 \times 3.2 ; \mathrm{FB} 97-081: \mathrm{m} 2=3.4$ x 3.1; FB 97-099: $\mathrm{M} 2=3.2 \times 4.8$; FB 97-108: $\mathrm{m} 1=3.0 \times 2.6$, $\mathrm{m} 2=3.3 \times 2.9, \mathrm{~m} 3=3.6 \times 2.6 ; \mathrm{FB} 97-110: \mathrm{M} 2=3.4 \times 4.6 ; \mathrm{UM}$ 102594: $\mathrm{M} 2=3.6 \times 5.1$.

\section{Hyopsodus powellianus Cope, 1884} Figure 6.3

1962 Hyopsodus browni (in part); Gazin, p. 65

Lectotype.-AMNH 4147, dentary m1-3, from unknown locality, Bighorn Basin, Wyoming.

Occurrence.-Localities FB-1, 15 late middle early Eocene, Wasatchian biochronologic zone Wa-6 (FB-15) and late early Eocene, Wasatchian biochronologic zone Wa-7 (FB-1), main

Figure 6. (1) FOBU 6213, Hyopsodus minor, left dentary m1-3 in occlusal view. (2) FOBU 6370, Hyopsodus minor, left maxilla M1-2 in occlusal view. (3) FOBU 6129, Hyopsodus powellianus, left dentary m2-3 in occlusal view. (4) FOBU 6297, Apheliscus cf. A. insidiosus, right p4 in occlusal (top) and buccal (bottom) views. (5) FOBU 6318, Haplomylus cf. H. scottianus, left dentary p3-4 in occlusal view. (6) FOBU 6437, Haplomylus cf. H. scottianus, right m2 in occlusal view. (7) FOBU 6365, Phenacodus trilobatus, left lower molar fragment (most of trigonid and a portion of the lingual margin missing) in occlusal view. (8-9) FOBU 6229, Ectocion superstes, left broken P4 (left, labial edge missing) and M1 (right, broken labially) in occlusal views. Scale bars = 5 mm. 

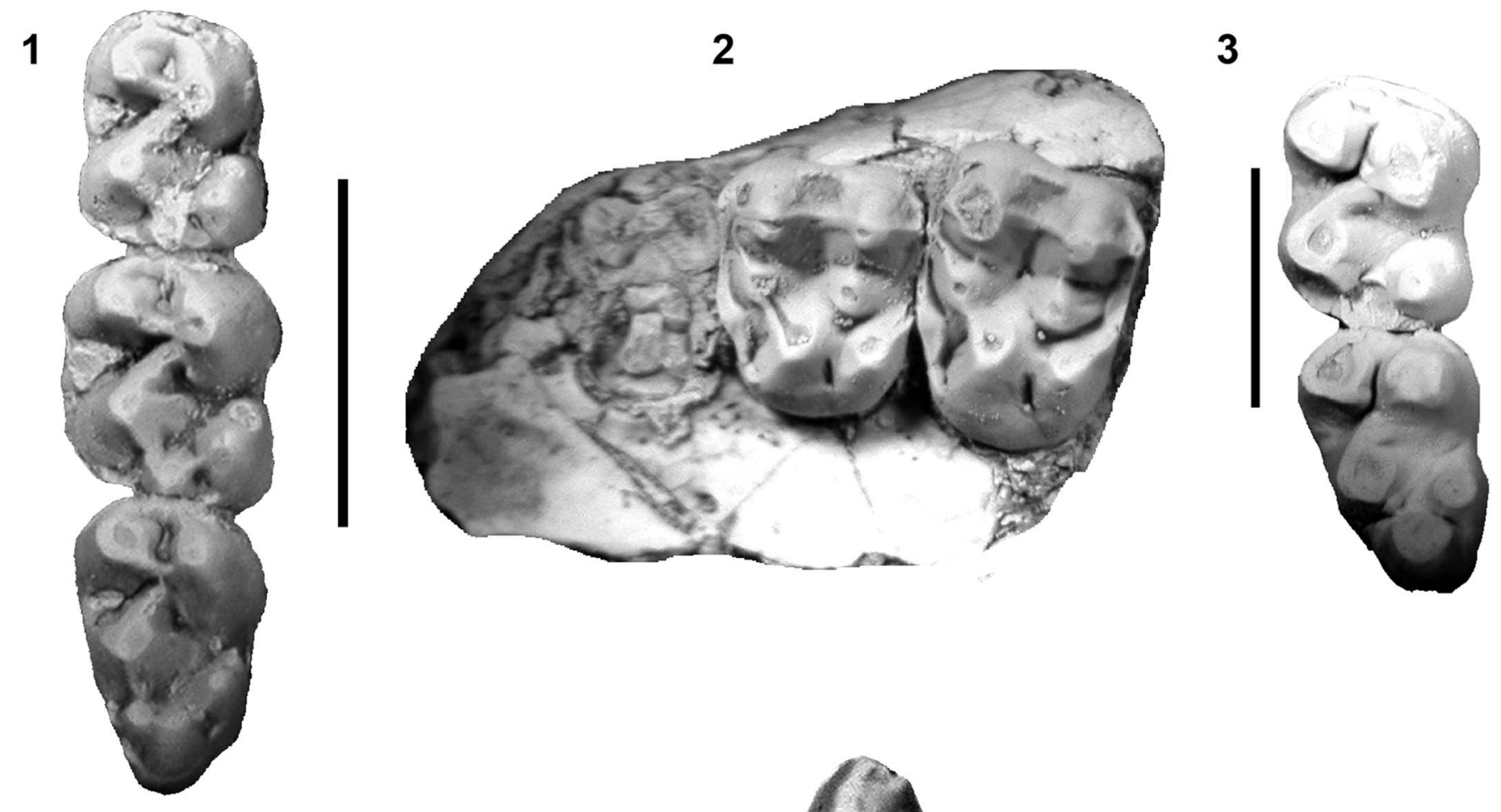

4
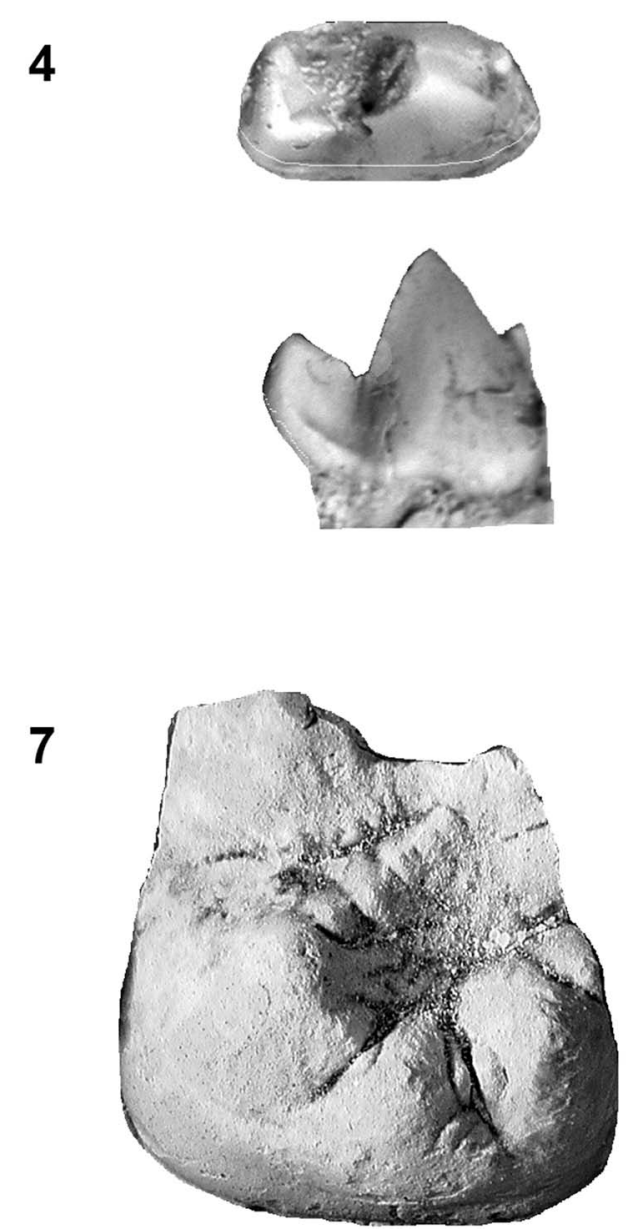

8

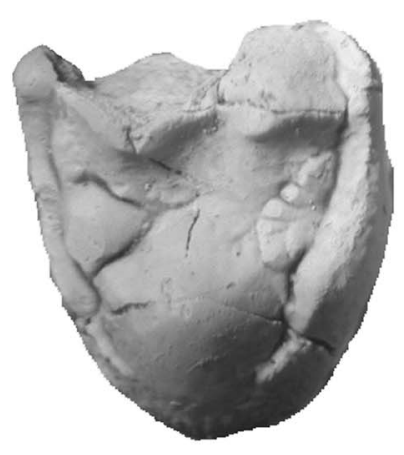

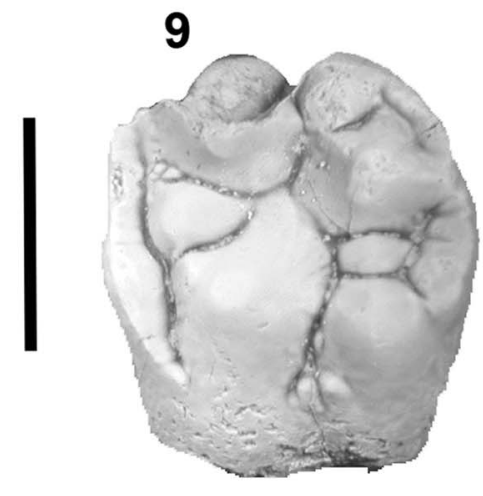


body, Wasatch Formation, Fossil Basin, Lincoln County, Wyoming.

Materials.-FB-1: FOBU 6129, left dentary m2-3; FB 96-035, left maxilla P4-M2. FB-15: FB 97-066, left maxilla M2-3.

Remarks. - These teeth are intermediate in size between Hyopsodus powellianus and Hyopsodus paulus (Redline, 1997). The M2 is within the size range of Hyopsodus paulus, but P4 is larger than the observed range for this species (Redline, 1997), falling instead within the size range of $H$. powellianus. The lower teeth are within the lower size range for $H$. powellianus, therefore we identify all of these specimens as that species. Large species of Hyopsodus are relatively rare from biochron Wa-6 in the Green River Basin (Gazin, 1962). Gazin (1962, p. 65) identified two large Hyopsodus specimens as H. browni, a maxilla with partial M2 and M3 from "high on the southwest slope of Fossil Butte," in the deeper red beds just beneath the Green River (near UM Localities FB-1 and FB-27) and a dentary with $\mathrm{m} 2$ and part of $\mathrm{m} 3$ from "the saddle on the north side of Fossil Butte" (near UM Locality FB-22). We consider these specimens to represent $H$. powellianus.

Measurements.-FOBU 6129: $\mathrm{m} 2=5.1 \times 4.1, \mathrm{~m} 3=5.9 \times 3.7$; FB 96-035: P4 = 4.0 x 4.7; FB 97-066: M2=4.1 x 5.5.

Genus Apheliscus Cope, 1875

Type species.-Prototomus insidiosus Cope, 1874, San Juan Basin, New Mexico.

\section{Apheliscus cf. A. insidiosus (Cope, 1874)}

Figure 6.4

\section{Prototomus insidiosus Cope, p. 14}

Holotype.-Unnumbered, dentary p4-m3 (specimen lost), from unknown locality, Biochron Wa7, San Jose Formation, New Mexico.

Occurrence.-Locality FB-16, late middle early Eocene, Wasatchian biochronologic zone Wa-6, main body, Wasatch Formation, Fossil Basin, Lincoln County, Wyoming.

Materials._FOBU 6297, right dentary p4.

Remarks. - This p4 is in the size range of A. insidiosus but differs from that species by possessing a small, anterior basal cuspule. Apheliscus is never especially abundant and is exceedingly rare in Wa- 6 , being represented in this biochron only by: (1) the type specimen of A. insidiosus from the San Juan Basin in New Mexico (the type has been lost for over 80 years, and no other specimens of Apheliscus have been reported from the San Juan Basin; see Rose, 1981); (2) the above specimen from Fossil Butte; (3) a few specimens from the Bighorn Basin in northwestern Wyoming (personal communication, K.D. Rose, 2015); and (4) a single reported specimen from the Wind River Basin in south-central Wyoming (Guthrie, 1967).
Apheliscus apparently disappeared by the end of Wa-6 elsewhere (Woodburne et al., 2009).

Measurements.-FOBU 6297: p4 = 3.1 x 1.7 .

Genus Haplomylus Matthew, 1915a

Type species.-Microsyops sperianus Cope, 1880, Bighorn Basin, Wyoming.

\section{Haplomylus cf. H. scottianus Gingerich, 1994}

Figure 6.5-6.6

1994 Haplomylus scottianus Gingerich, p. 126, figs. 3c, 3g, 4

Holotype.-UM 92489, left dentary p4-m3, Wasatchian Biochron Wa5, Willwood Formation, Bighorn Basin, Wyoming.

Occurrence.-Localities FB-11, 18, 19, late middle early Eocene, Wasatchian biochronologic zone Wa-6, main body, Wasatch Formation, Fossil Basin, Lincoln County, Wyoming.

Materials.-FB-11: FOBU 6437, right dentary m2. FB-18: FOBU 6304, right dentary with talonid of $\mathrm{p} 4$ and $\mathrm{m} 1$ with broken trigonid. FB-19: FOBU 6318, left dentary p3-4.

Remarks.-These specimens are in the size range of H. scottianus (Gingerich, 1994), but differ from that species in having a simpler, relatively shorter p4 talonid, a weaker paracristid on $\mathrm{m} 2$, and a much weaker hypoconulid on $\mathrm{m} 1-2$. These specimens may prove to represent a species distinct from $H$. scottianus when better samples are discovered. These records (Wa-6) of Haplomylus are the latest known occurrences of the genus, whereas it apparently disappears by the end of Wa-5 elsewhere (Gazin, 1962; Gingerich, 1994).

Measurements.-FOBU 6437: $\mathrm{m} 2=2.7$ x 2.5; FOBU 6304: $\mathrm{m} 1=2.6 \times 2.1 ;$ FOBU 6318: p3 = $3.2 \times 1.6, \mathrm{p} 4=3.4 \times 1.9$.

Family Phenacodontidae Cope, 1881

Genus Phenacodus Cope, 1873

Type species.-Phenacodus primaevus Cope, 1873, Green River Basin, Wyoming.

\section{Phenacodus trilobatus Cope, 1882b} Figure 6.7

Holotype.-AMNH 4679, left dentary m1-3, locality unknown, middle to late Wasatchian, Willwood Formation, Bighorn Basin, Wyoming.

Occurrence.-Locality FB-11, late middle early Eocene, Wasatchian biochronologic zone Wa-6, main body, Wasatch Formation, Fossil Basin, Lincoln County, Wyoming.

Materials._FOBU 6365, left lower molar trigonid (worn).

Remarks.-This specimen preserves only enough morphology to indicate that it represents a relatively large species of Phenacodus. 
Phenacodus trilobatus is similar in size and is known from the late Wasatchian (Thewissen, 1990), therefore this specimen is accordingly identified as that species.

Measurements.-No standard measurements are possible on this broken specimen.

\section{Genus Ectocion Cope, $1882 \mathrm{c}$}

Type species.-Oligotomus osbornianus Cope, 1882c, Bighorn Basin, Wyoming.

\section{Ectocion superstes Granger, 1915}

Figure 6.8-6.9

Holotype--AMNH 233A, dentary c1, p3-m3, Bridgerian Biochron Brla, Wind River Formation, Wind River Basin, Wyoming.

Occurrence.-Locality FB-16, late middle early Eocene, Wasatchian biochronologic zone Wa-6, main body, Wasatch Formation, Fossil Basin, Lincoln County, Wyoming.

Materials._FOBU 6229, left P4 and M1, both broken.

Remarks.-Besides these two fragments of E. superstes from Fossil Butte, the only other known sample of this rare phenacodontid comes from the earliest Bridgerian (Brla) in the Wind River Basin of Wyoming (Thewissen, 1990). These two fragmentary teeth from Wa-6 at Fossil Butte represent the earliest known occurrence of this species.

Measurements.-No measurements are possible.

Family Meniscotheriidae Cope, 1882d

Genus Meniscotherium Cope, 1874

Type species.-Meniscotherium chamense Cope, 1874, San Juan Basin, New Mexico.

\section{Meniscotherium cf. M. robustum Thorpe, 1934}

1934 Mensicotherium robustum Thorpe, p. 401, figs. 1-4

1962 Meniscotherium robustum (in part); Gazin, p. 68

Holotype.-YPM 10101, skull, dentary, Knight beds (= Wasatch Formation), middle to late Wasatchian, near Aspen, Wyoming.

Occurrence.-Locality FB-15, late middle early Eocene, Wasatchian biochronologic zone Wa-6, main body, Wasatch Formation, Fossil Basin, Lincoln County, Wyoming.

Materials.-FB-15: FBF 155 (= USNM 22670), left dentary p4-m2, right dentary $\mathrm{m} 1$, left maxilla M1-2, associated postcranial fragments.

Remarks.-As discussed by Gazin (1962), Meniscotherium is extremely rare in Fossil Basin, which seems odd given that it is abundant from correlative beds in the adjacent Green River Basin. Gazin (1962, p. 68) noted the presence of this one specimen of Meniscotherium from "high on Fossil Butte" (UM FB-15) that he hesitantly assigned to M. robustum.

Measurements.-FBF 155: $\mathrm{p} 4=8.0 \times 5.5, \mathrm{~m} 1=8.0 \times 5.8$, $\mathrm{m} 2=9.0 \times 6.8$.

Order Mesonychia Matthew, 1937

Family Mesonychidae Cope, 1875 Mesonychid sp. indet.

Occurrence.- "Low on slope of Fossil Butte" (Gazin, 1962, p. 51; probably in the vicinity of UM localities FB-4, FB-11, and FB-26), late middle early Eocene, Wasatchian biochronologic zone Wa-6, main body, Wasatch Formation, Fossil Basin, Lincoln County, Wyoming.

Remarks.-Gazin (1962, p. 51) noted the presence of a fragmentary lower cheek tooth of a mesonychid from Fossil Butte. He identified this tooth as Pachyaena gracilis, but noted that it seemed rather small and reminiscent of Dissacus as well. In either case, it represents the only known record of a mesonychid from Fossil Butte.

Order Rodentia Bowdich, 1821

Family Ischyromyidae Alston, 1876

Subfamily Reithroparamyinae Wood, 1962

Genus Reithroparamys Matthew, 1920

Type species.-Paramys delicatissimus Leidy, 1871, Green River Basin, Wyoming.

Reithroparamys cf. R. debequensis Wood, 1962

1962 Reithroparamys debequensis Wood, p. 134, fig. 45D-G

1962 Reithroparamys sp., Gazin, p. 46

Holotype.-FMNH (CNHM) P-26726, left dentary i1, m1-3, Wasatchian Biochron Wa6, Debeque Formation, near Rifle, Colorado.

Occurrence.-Saddle north of Fossil Butte (near UM Localities FB-22 and FB-28), late middle early Eocene, Wasatchian biochronologic zone Wa-6, main body, Wasatch Formation, Fossil Basin, Lincoln County, Wyoming.

Materials.-USNM 22380, left dentary i1, m1.

Remarks.-A single specimen of Reithroparamys is represented at Fossil Butte, questionably identified as $R$. debequensis by Wood (1962). He noted that it was similar to $R$. debequensis but that the molar was much narrower than other specimens.

$$
\begin{gathered}
\text { Subfamily Paramyinae Haeckel, } 1895 \\
\text { Genus ?Notoparamys Korth, } 1984
\end{gathered}
$$

Type species.-Leptotomus costilloi Wood, 1962, Huerfano Basin, Colorado.

?Notoparamys blochi new species Figure 7.1-7.4 

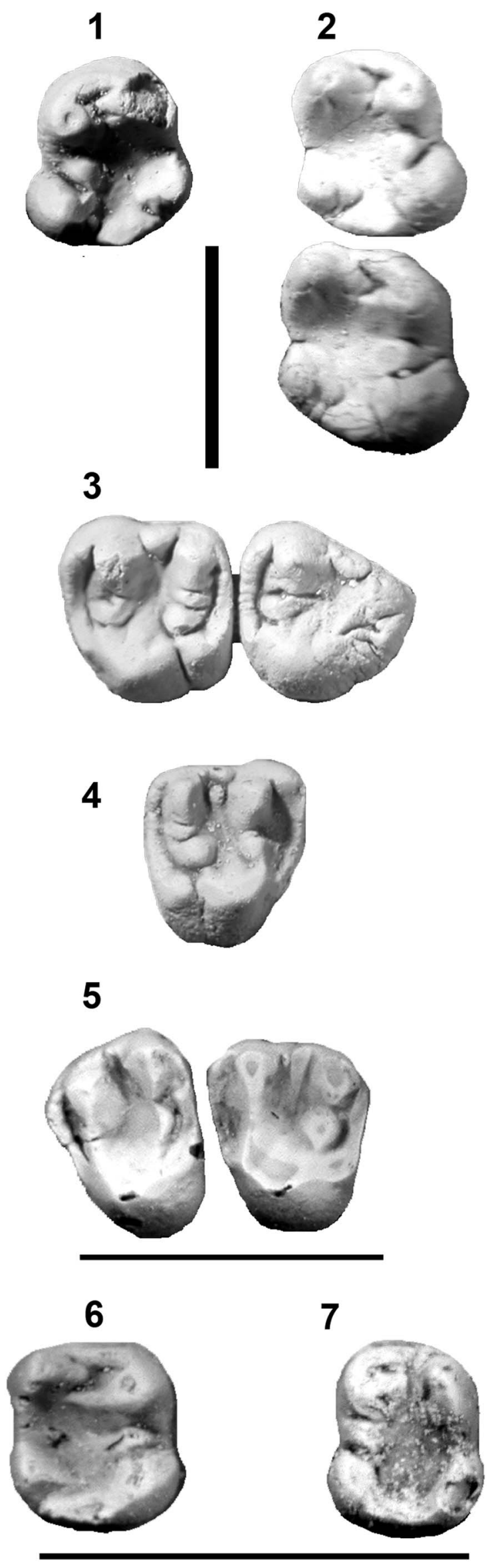

Holotype.-Holotype and only specimen, FOBU 6092, associated left dentary $\mathrm{m} 1$, right dentary $\mathrm{m} 1-2$, left maxilla M2-3, right maxilla M1, and postcranial fragments, found by Jonathan I. Bloch, July 30, 1997, from locality FB-15, late middle early Eocene, Wasatchian biochronologic zone Wa-6, main body, Wasatch Formation, Fossil Basin, Lincoln County, Wyoming.

Diagnosis.—?Notoparamys blochi $\mathrm{n}$. $\mathrm{sp}$. differs from Notoparamys costilloi in having an unreduced M3, a less transversely elongate hypoconulid on lower molars, an m1-2 mesoconid that is connected to the base of the protoconid and to the anterolingual base of the hypoconid (i.e., complete ectolophid), in lacking a protoconid loph that extends into the trigonid basin, and in lacking full development of the distinctive double-ridged connection between the hypoconulid and entoconid that is apparently typical of Notoparamys (Korth, 1984 and discussion below); differs from $N$. arctios in being substantially larger in tooth dimensions (on average 25\% larger in linear dimensions), but does resemble this species in lacking a protoconid extension into the trigonid basin.

Description.-The holotype (and only) specimen of ?Notoparamys blochi $\mathrm{n}$. sp. is known from upper and lower molars. Lower $\mathrm{m} 1$ and $\mathrm{m} 2$ are similar in having bulbous and marginally placed proto-, meta-, hypo-, and entoconids, with the hypoconid being the most robust cusp, followed by the metaconid. The hypoconid bulges buccally towards its base and is essentially separated from the protoconid by a distinct, low mesoconid (the mesoconid is connected to both the proto- and hypoconid on $\mathrm{m} 1$ ). There is a distinct, crescentic hypoconulid present that is centered on posterolophid of each tooth (not more lingually placed as noted for Notoparamys by Korth, 1984) and separated from both the hypoconid and entoconid by narrow valleys. There is a short crest that extends from the buccal base of the entoconid posterobuccally toward the hypoconulid but does not reach that cusp. The hypoconulid is not connected to the entoconid by an additional crest posterior to the one from the entoconid, instead being separated posteriorly from the entoconid by a tiny cuspule. Lower $\mathrm{m} 2$ differs from $\mathrm{m} 1$ in being slightly larger with a slightly more anteroposteriorly compressed metalophid.

Upper molars are all similar to one another and share the following morphological features. Protocones are rounded and robust and paracones. Metacones are distinct and relatively smaller than the protocone, especially on M1-2. A distinct hypocone is present on M1 and M2 (absent on M3) that is separated from the protocone by a sharply defined groove as in Notoparamys. Hypocones do not extend as far lingually as the protocones. Robust and bulbous mesostyles are present on all molars, with M3 having at least three small mesostylar cusps. Incipiently doubled potoconules (best seen on M2-3) and

Figure 7. (1-2) FOBU 6092, ?Notoparamys blochi n. sp. (Holotype), left $\mathrm{m} 1$ (left) and right dentary m1-2 (right) in occlusal view. (3-4) FOBU 6092, ? Notoparamys blochi $\mathrm{n}$. sp. (Holotype), left maxilla M2-3 (top) and right M1 (bottom) in occlusal view. (5) FOBU 6182, Paramys excavatus, left maxilla P4-M1 in occlusal view. (6-7) FOBU 6161, Knightomys depressus, right m2 (left) and FOBU 6408, Knightomys depressus, left $\mathrm{m} 1$ (right) in occlusal view. Scale bars $=5 \mathrm{~mm}$. 
distinctly doubled metaconules are found on all three molars, the latter feature being shared with Notoparamys (and other paramyines as well, see Rose and Von Koenigswald, 2007 for discussion). Pre- and postcingula are well developed and anteroposteriorly broad.

M1 differs from M2 in being somewhat smaller and anteroposteriorly narrower with a less broad trigon fovea (basin). M3 differs from both $\mathrm{M} 1$ and $\mathrm{M} 2$ in lacking a hypocone and in having a more robust and relatively larger protocone. It also differs from the other molars in having a rounded and posteriorly directed metacone, a double-crested metaloph with the posterior branch reaching the postcingulid and forming a small cuspule there, and in being somewhat more triangular in shape rather than more rhomboidal like M1-2.

Etymology.-For Jonathan I. Bloch, who discovered the type specimen and for his many contributions to the recovery and study of fossil mammals from Wyoming and elsewhere.

Remarks.-Rose and Von Koenigswald (2007) discussed the complicated history of Notoparamys and described a highly variable sample of what they referred to as $N$. costilloi from Wa-6 in the Bighorn Basin of northwestern Wyoming. They noted that many (most) of the distinctive characters used to diagnose this genus (hypocone distinct and adjacent to metaconule on M1-2, M3 smaller than M1-2, mesoconid large and isolated on lower molars, hypoconulid wide and connected to entoconid by a pair of ridges enclosing a tiny basin that may be open posteriorly, accessory lophid extends from metaconid into trigonid fovea, low incisor flattened medially, rounded laterally, see Korth, 1984, 1994b; Anderson, 2008) are variably present or absent and variably developed or not in the Bighorn Basin sample.

?Notoparamys blochi $\mathrm{n}$. sp. is no exception, with only a distinct hypocone and an accessory lophid extending from the metaconid into the trigonid fovea on the lower molars being definitively shared in common with the genotype species, $N$. costilloi. The double-ridge connection of the hypoconulid to the entoconid is only incipient (see description above) on the m1-2 of ?N. blochi. Korth (1984) indicated that both of these ridges originated from the lingual end of the hypoconulid in Notoparamys but it is apparent from the m1-2 of ?N. blochi that the more mesial of these ridges likely originated from the entoconid and extended posterobucally to eventually reach the hypoconulid. The more posterior of these ridges is described as being "broken at its center by narrow valley" (Korth, 1984, p. 21). In ?N. blochi, the posterior ridge is clearly differentiated from the entoconid by a rather distinct valley on $\mathrm{m} 1$ while that valley is partially bridged by a small cuspule located between the entoconid and hypoconulid on $\mathrm{m} 2$.

We tentatively assign this new species to ?Notoparamys. However, we note that, aside from the type sample from Huerfano (Wood, 1962; Robinson, 1966; Korth, 1984), it is questionable whether or not any of the other specimens assigned to Notoparamys (Korth, 1984; Rose and Chinnery, 2004; Rose and Von Koenigswald, 2007) actually belong to that genus, and if they do, whether or not the genus can be sustained as defined given that virtually every character cited in the diagnosis is so variable as to often be completely absent. We believe that, at the generic level especially, diagnostic characters must be those that are present in all specimens whether or not they are weakly or more strongly formed.

Measurements.-FOBU 6092: $\mathrm{M} 1=3.7$ x 4.3, M2 $=3.8 \times 4.3$, $\mathrm{M} 3=4.3 \times 3.9, \mathrm{~m} 1=4.1 \times 3.5, \mathrm{~m} 2=4.5 \times 3.8$.

Genus Paramys Leidy, 1871

Type species.-Paramys delicatus Leidy, 1871 (as designated by Wood, 1962), Green River Basin, Wyoming.

Paramys excavatus Loomis, 1907

Figure 7.5

Holotype.-ACM 327, right dentary p4-m3, Wasatchian Biochron a6, Wind River Formation, Bridger Creek, Wyoming.

Occurrence.-Localities FB-1, 10, 18, 19, late middle early Eocene, Wasatchian biochronologic zone Wa-6 (FB-10, 18-19) and late early Eocene, Wasatchian biochronologic zone Wa-7 (FB-1), main body, Wasatch Formation, Fossil Basin, Lincoln County, Wyoming.

Materials.-FB-1: FB 96-038, left dentary i1; FB 96-039, left m1. FB-10: FOBU 6182, left maxilla P4-M1. FB-18: FB 97-079, left p4. FB-19: FB 97-096, left maxilla P4.

Remarks.-These specimens are in the size range of the relatively common taxon Paramys excavatus (Wood, 1962) and probably all represent that species.

Measurements.-FB 96-039: $\mathrm{m} 1=3.1 \times 3.0 ;$ FOBU 6182: $\mathrm{P} 4=$ $2.7 \times 3.3, \mathrm{M} 1=2.7 \times 3.3 ; \mathrm{FB} 97-079: \mathrm{p} 4=2.6 \times 2.1$.

Paramyinae sp. indet.

Occurrence.-Locality FB-16, late middle early Eocene, Wasatchian biochronologic zone Wa-6, main body, Wasatch Formation, Fossil Basin, Lincoln County, Wyoming.

Materials.-FOBU 6283, right M2.

Remarks.-This tooth represents a small paramyine, larger than Microparamys, but smaller than other known paramyines. M2 is almost square with a relatively small, indistinct, posteriorly placed hypocone, a relatively strong, isolated metaconule, and a tiny mesostyle. This tooth may represent a new paramyine genus, but more complete specimens are required to be certain.

Measurements.-FB 6283: M2 $=2.1 \times 2.2$

Family Sciuravidae Miller and Gidley, 1918 Genus Knightomys Gazin, 1961

Type species.-Tillomys senior Gazin, 1952, Green River Basin, Wyoming. 


\section{Knightomys depressus Loomis, 1907}

Figure 7.6-7.7

Holotype-ACM 432, skull with right M1-3, left I1, Wasatchian Biochron Wa6, Wind River Formation, Wyoming.

Occurrence.-Localities FB-1, 4, late middle early Eocene, Wasatchian biochronologic zone Wa-6 (FB-4) and late early Eocene, Wasatchian biochronologic zone Wa-7 (FB-1), main body, Wasatch Formation, Fossil Basin, Lincoln County, Wyoming.

Materials.-FB-1: FOBU 6161, right m2. FB-4: FOBU 6408, left $\mathrm{m} 1$.

Remarks.-These two specimens represent a sciuravid larger than Knightomys senior (Gazin, 1952) and are similar in size to $K$. depressus (Loomis, 1907). The type sample of $K$. depressus is from the Wa-6 horizon in the Wind River Basin (Wood, 1965), but the species may range into the Bridgerian (Korth, 1994b).

Measurements.—FOBU 6161: $\mathrm{m} 2=2.0$ x 1.9; FOBU 6408: $\mathrm{m}=2.0 \times 1.7$.

\section{Knightomys huerfanensis (Wood, 1962)}

1962 Paramys huerfanensis Wood, p. 62

1966 Paramys huerfanensis; Robinson, p. 45

Holotype.-AMNH 55114, right dentary p4-m3, Bridgerian Biochron Brla, Locality II, Huerfano Formation, Colorado.

Occurrence.-Locality FB-19, late middle early Eocene, Wasatchian biochronologic zone Wa-6, main body, Wasatch Formation, Fossil Basin, Lincoln County, Wyoming.

Materials._FOBU 6397, left M2.

Remarks.-This single tooth represents a relatively large species of Knightomys. It is of similar size to K. huerfanensis and, like that species, has relatively robust and rounded cusps, especially the protocone and hypocone (Korth, 1984). This specimen represents the earliest known occurrence (Wa-6) of $K$. huerfanensis, otherwise only known from the latest Wasatchian (Wa-7) and earliest Bridgerian (Br-1a).

Measurements.-FOBU 6397: $\mathrm{M} 2=2.3 \times 2.5$.

Order Oxyaenodonta Van Valen, 1971

Family Oxyaenidae Cope, 1877

Subfamily Oxyaeninae Cope, 1877

Genus Oxyaena Cope, 1874

Type species.—Oxyaena lupina Cope, 1874, San Juan Basin, New Mexico.

Oxyaena forcipata Cope, 1874

Figure 8.1-8.2
Holotype.-USNM 1029, left and right dentaries, Wasatchian Biochron Wa7, San Jose Formation, San Juan Basin, New Mexico.

Occurrence.-Locality FB-7, late middle early Eocene, Wasatchian biochronologic zone Wa-6, main body, Wasatch Formation, Fossil Basin, Lincoln County, Wyoming.

Materials._UM 102584, left dp4.

Remarks.-This specimen represents a relatively large species of Oxyaena. The Wa-6 form, O. forcipata, is of the right size and morphology, and we identify UM 102584 as this species.

Measurements.-UM 102584: dp4 length $=13.9 \mathrm{~mm}$ (a width measurement is not possible on this broken specimen).

Order Hyaenodonta Van Valen, 1967
Genus Prototomus Cope, 1874

Type species.-Prototomus viverrinus Cope, 1874, San Juan Basin, New Mexico.

Prototomus secundarius Cope, 1875 Figure 8.3-8.4

1962 Sinopa, cf. S. multicuspis (in part); Gazin, p. 55

Holotype.-USNM 1025, left and right dentary fragments, Wasatchian Biochron Wa7, San Jose Formation, San Juan Basin, New Mexico.

Occurrence.-Locality FB-27, late middle early Eocene, Wasatchian biochronologic zone Wa-6, main body, Wasatch Formation, Fossil Basin, Lincoln County, Wyoming.

Materials.—FOBU 6380, right P4, left maxilla P3-M1.

Remarks.-These specimens represent an intermediatesized hyaenodontid and are of appropriate size and morphology to be identified as $P$. secundarius. An additional specimen, probably referable to $P$. secundarius, from "high on Fossil Butte" (Gazin, 1962, p. 55; near UM Localities FB-1 and FB-27), is USNM 22460, a fragmentary right maxilla with two broken molars.

Measurements.-FOBU 6380: $\mathrm{P} 3=5.0 \times 2.7, \mathrm{P} 4=5.5 \times 5.0$, $\mathrm{M} 1=6.0 \times 7.2$.

Hyaenodontid sp. indet.

Occurrence.-Localities FB-13, 18, late middle early Eocene, Wasatchian biochronologic zone Wa-6, main body, Wasatch Formation, Fossil Basin, Lincoln County, Wyoming.

Materials.-FB-13: FB 97-004, right maxilla, P2 fragment. FB-18: FB 97-077, postcrania.

Remarks.-These two specimens represent hyaenodontids, but it is not possible to identify either to genus or species. 

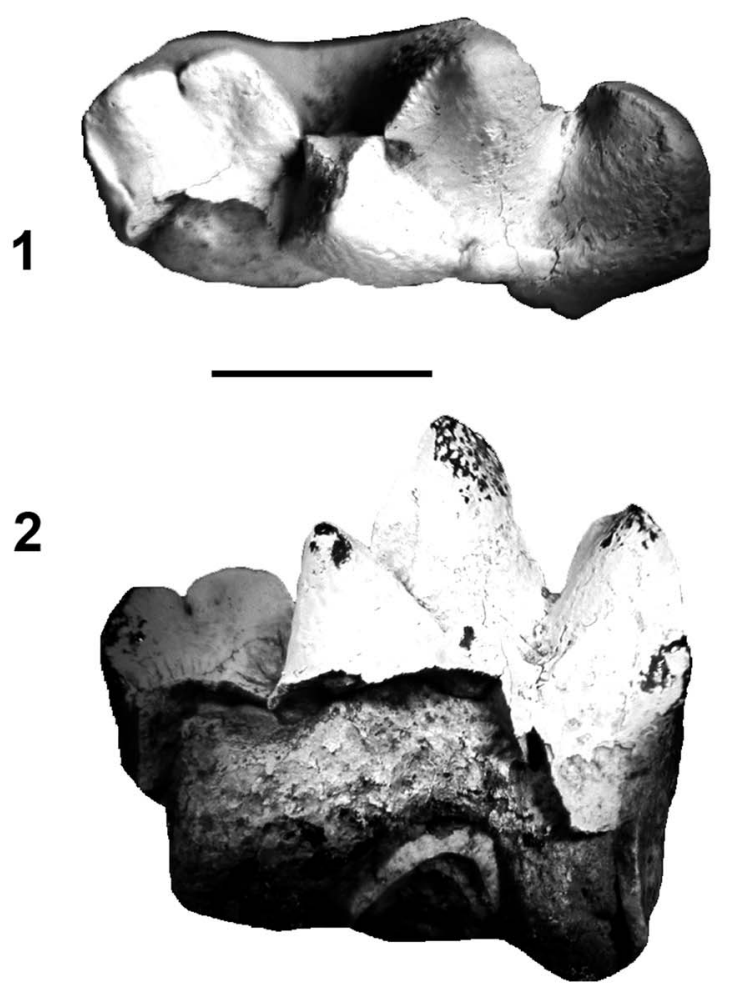

3
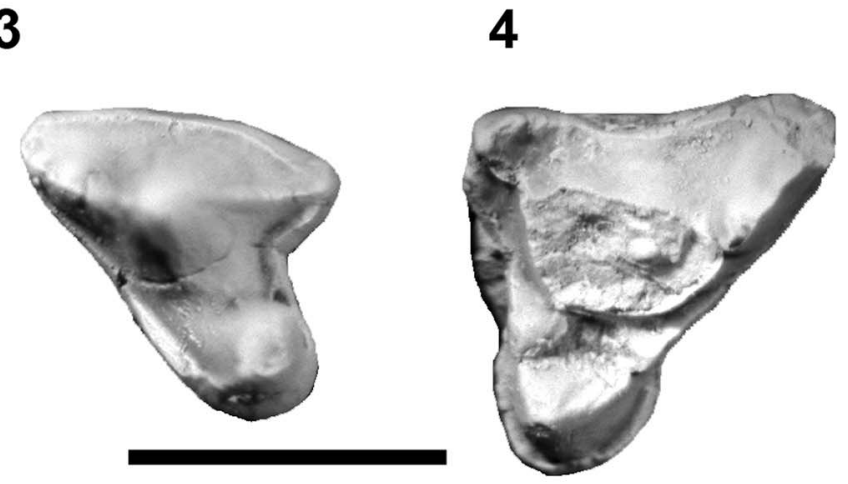

5

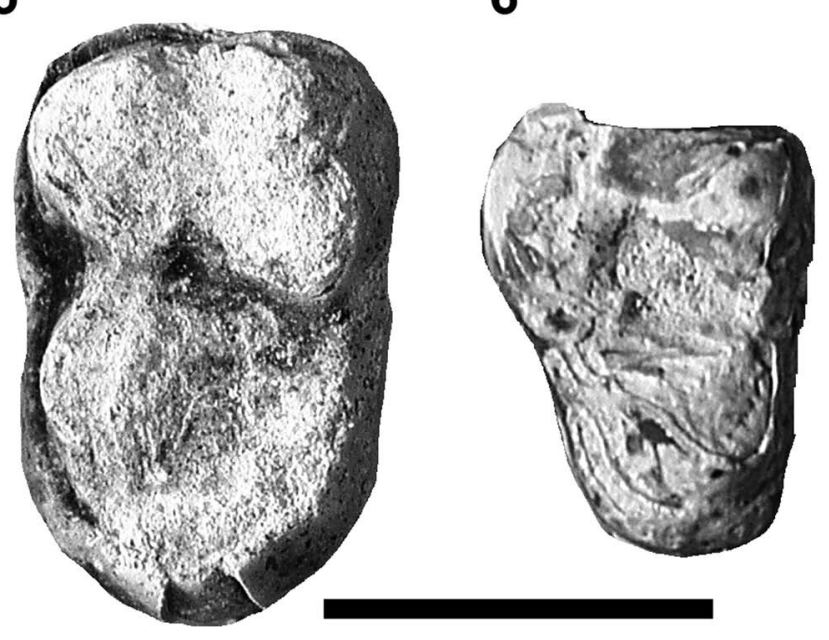

Order Carnivora Bowdich, 1821

Family Viverravidae Wortman and Matthew, 1899

Genus Viverravus Marsh, 1872

Type species.-Viverravus gracilis Marsh, 1872, Green River Basin, Wyoming.

\section{Viverravus sp. indet.}

Occurrence.-Localities FB-8, 9, late middle early Eocene, Wasatchian biochronologic zone Wa-6, main body, Wasatch Formation, Fossil Basin, Lincoln County, Wyoming.

Materials.-FB-8: FOBU 6148, right P4 fragment. FB-9: FOBU 6177, left dentary p4-m2, teeth broken.

Remarks.-These two specimens confirm the presence of Viverravus at Fossil Butte. They are too fragmentary for specific determination.

Genus Didymictis Cope, 1875

Type species.-Limnocyon protenus Cope, 1874, San Juan Basin, New Mexico.

\section{Didymictis cf. D. protenus (Cope, 1874)}

Figure 8.5-8.6

1874 Limnocyon protenus Cope, p. 15

1882a Didymictis curtidens Cope, p. 160

1962 Didymictis altidens (in part); Gazin, p. 57

Holotype.-USNM 1092, left and right dentaries, Wasachian Biochron Wa7, San Jose Formation, San Juan Basin, New Mexico.

Occurrence.-Localities FB-1, 5, 7, late middle early Eocene, Wasatchian biochronologic zone Wa-6 (FB-5, 7) and late early Eocene, Wasatchian biochronologic zone Wa-7 (FB-1), main body, Wasatch Formation, Fossil Basin, Lincoln County, Wyoming.

Materials.-FB-1: FOBU 6120, left $\mathrm{m} 1$ trigonid. FB-5: FOBU 6385, left m2. FB-7: UM 108143, left M1.

Remarks.-These specimens represent a medium-sized species of Didymictis. They are similar in size to D. protenus and smaller than D. altidens. Gazin (1962, p. 57) tentatively assigned some tooth fragments from the "higher slopes of Fossil Butte" (probably near UM Localities FB-1 and FB-27) to $D$. altidens. We believe it is more probable that they represent D. protenus.

Figure 8. (1-2) UM 102584, Oxyaena forcipata, left dp4 with broken labial trigonid and lingual talonid in occlusal (top) and lingual (bottom) views. (3) FOBU 6380, Prototomus secundarius, right P4 in occlusal view. (4) FOBU 6380, Prototomus secundarius, left broken M1 in occlusal view. (5) FOBU 6385, Didymictis cf. D. protenus, left $\mathrm{m} 2$ in occlusal view. (6) UM 108143 , Didymictis cf. D. protenus, left M1 (broken) in occlusal view. Scale bars $=5 \mathrm{~mm}$. 
Measurements.-FOBU 6385: $\mathrm{m} 2=8.0 \times$ 4.7; UM 108143: $\mathrm{M} 1=7.0 \times 9.9$.

Family Miacidae Cope, 1880

Genus Vulpavus Marsh, 1871

Type species.-Vulpavus palustris Marsh, 1871, Green River Basin, Wyoming.

\section{Vulpavus australis Savagea}

\section{2 cf. Vulpavus australis; Gazin, p. 60}

Holotype.-AMNH 16226, left dentary p4-m3, Wasatchian Wa7, San Jose Formation, San Juan Basin, New Mexico.

Occurrence.-_"High on the slope of Fossil Butte" (Gazin, 1962, p. 60; probably near UM Localities FB-1 and FB-27), late middle early Eocene, Wasatchian biochronologic zone Wa-6 (FB-27) or late early Eocene, Wasatchian biochronologic zone Wa-7 (FB-1), main body, Wasatch Formation, Fossil Basin, Lincoln County, Wyoming.

Materials._USNM 22474, right M1.

Remarks.-Gazin (1962, p. 60) noted the presence of a single tooth of Vulpavus from Fossil Butte. This specimen conforms in size and morphology with $V$. australis.

\section{Miacid sp. A \& B indet.}

Occurrence.-Localities FB-1, 5, 7, late middle early Eocene, Wasatchian biochronologic zone Wa-6 (FB-5, 7) and late early Eocene, Wasatchian biochronologic zone Wa-7 (FB-1), main body, Wasatch Formation, Fossil Basin, Lincoln County, Wyoming.

Materials.-FB-1: FOBU 6109, right $\mathrm{m} 1$ trigonid. FB-5: FOBU 6110, right $\mathrm{m} 2$ talonid. FB-7: UM 102593, left m2 talonid.

Remarks.-These fragmentary specimens represent two different miacid carnivorans, but are too incomplete to be assigned to any particular genus or species.

\section{Order Perissodactyla Owen, 1848 \\ Family Equidae Gray, 1821 \\ Genus Protorohippus Wortman, 1886}

Type species.-Hyracotherium venticolum Cope, 1881, Wind River Basin, Wyoming.

\section{Protorohippus venticolum (Cope, 1881)}

Figure 9.1-9.2

1881 Hyracotherium venticolum Cope, p. 198

1886 Protorohippus venticolus; Wortman, p. 105

1908 Eohippus venticolus; Granger, p. 244

1952 Hyracotherium index (in part); Gazin, p. 66

1956 Hyracotherium vasacciense venticolum; Kitts, p. 50
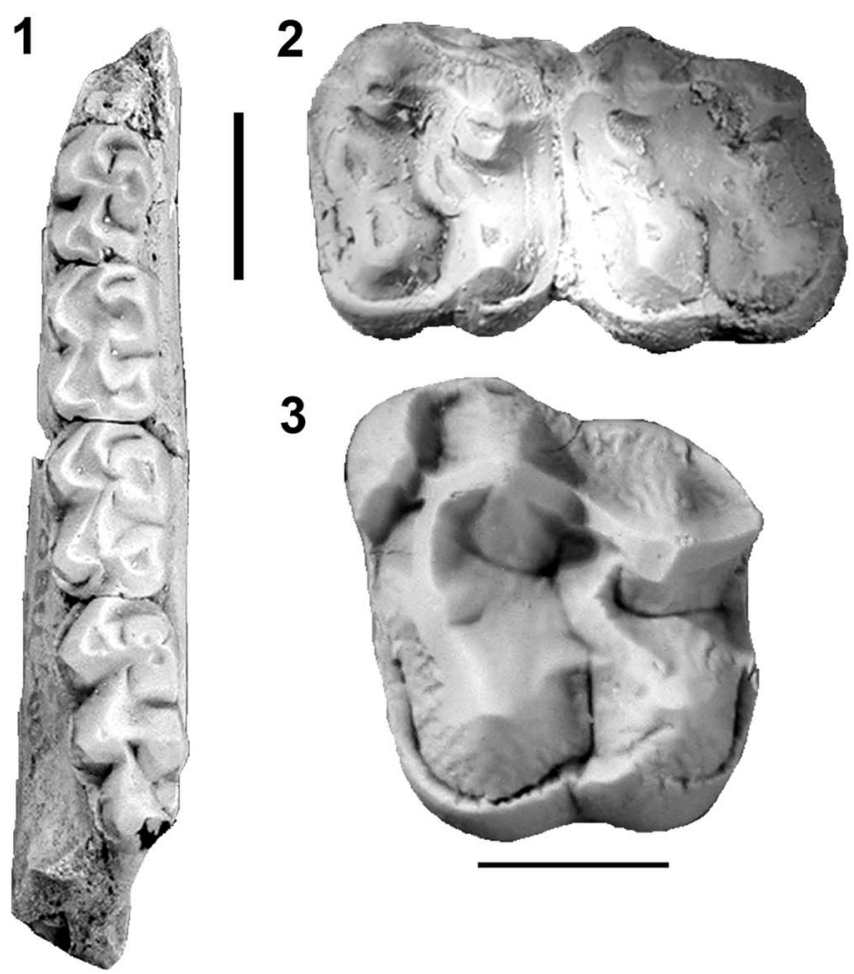

\section{3}
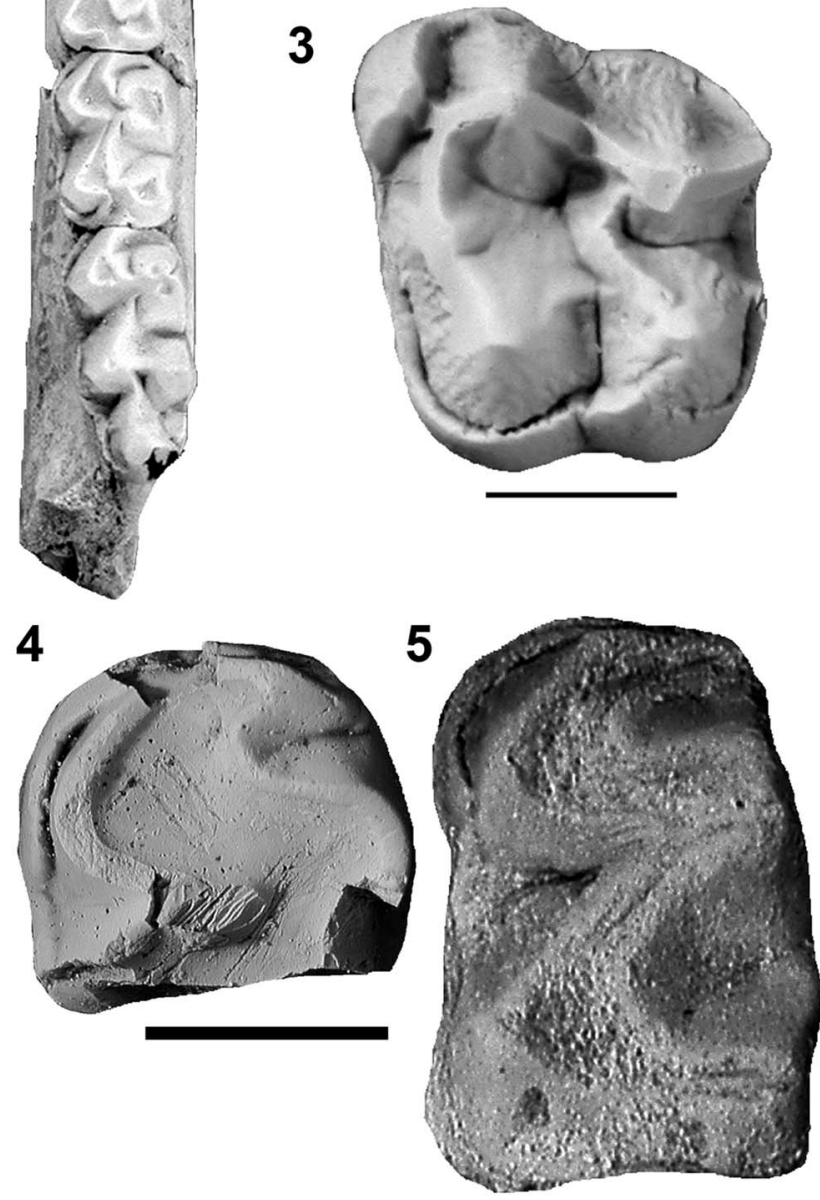

Figure 9. (1) FOBU 6378, Protorohippus venticolum, left dentary p4-m3 in occlusal view. (2) FOBU 6325, Protorohippus venticolum, left maxilla M2-3 in occlusal view. (3) FOBU 6179, Heptodon calciculus, left M1 in occlusal view. (4) FOBU 6154, Lambdotherium popoagicum, left $\mathrm{m} 1$ trigonid in occlusal view. (5) DPC 14810, Lambdotherium popoagicum, left $\mathrm{m} 1$ in occlusal view. Scale bars $=5 \mathrm{~mm}$.

1962 Hyracotherium vasacciense (in part); Gazin, p. 73

1967 Hyracotherium vasacciense; Guthrie, p. 43

2002 Protorohippus venticolum; Froehlich, p. 180

Holotype.-AMNH 4832, skull and skeleton, Wasatchian Biochron Wa7, Wind River Formation, Wind River Basin, Wyoming.

Occurrence.-Localities FB-4, 5, 7-9, 11, 14-16, 18, 19, 21, 22, 26, 27, 29, late middle early Eocene, Wasatchian biochronologic zone Wa-6, main body, Wasatch Formation, Fossil Basin, Lincoln County, Wyoming. 
Referred specimens.-FB-4: FOBU 6387, left Mx. FB-5: FB 95-006, left m1-2; FOBU 6404, right Mx. FB-7: UM 102583, right maxilla dP3-4-M1; UM 102590, right P3; UM 108137, left P2; UM 108139, right p4; UM 108140, left p3; UM 108141, right P4; UM 108142, right maxilla P2-M1. FB-8: FB 96-017, right dentary $\mathrm{m} 2$; FB 96-020, right $\mathrm{P} 3$, Mx. FB-9: FB 96-064, right p4; FB 96-073, left M3; FB 96-074, right P4; FB 97-019, left m2. FB-11: FOBU 6358, right dentary m3 (broken); FOBU 6374, left dp4, m2; FOBU 6375, left dentary, postcrania; FOBU 6378, left and right dentaries, right maxilla; FOBU 6383, left m3. FB-14: FB 97-025, left m1. FB-15: FB 97-027, left M3, left m3; FB 97-067, right M1. FB-16: FB 97-031, left maxilla M1-2, right m1; FB 97-032, right dentary m3; FB 97-034, left p4; FB 97-042, right dentary p3-m2, Mx; FB 97-071, left dentary m2; FOBU 6372, right dentary m1-2 (teeth broken); FOBU 6418, left m1. FB-18: FB 97-078, right m1. FB-19: FB 97-084, left dentary m2; FB 97-087, left maxilla M1-3; FB 97-090, right maxilla M1; FB 97-093, right dentary dp4-m3; FOBU 6382, right dentary p3-4, m2-3. FB-21: FB 97-103, left M3. FB-22: FOBU 6325, palate. FB-26: FB 97-114, left dentary m1; FB 97-117, right M2-3. FB-27: FOBU 6428, left p3. FB-29: FB 97-124, left dentary $\mathrm{m} 1$.

Remarks.-Equids are by far the most common mammals found at Fossil Butte. While there is some variation in tooth size, all of these specimens can be accommodated in Protorohippus venticolum, the most common Wa-6-Wa-7 species of North American equid (Froehlich, 2002). Gazin (1952, p 66) referred YPM-PU 16172 from three miles north of Fossil, Wyoming to Hyracotherium index. In 1962, Gazin noted that Kitts (1956) synonymized $H$. index with $H$. vasacciense. Gazin (1962, p. 73) reallocated all of the specimens he had assigned to $H$. index in 1952 to $H$. vasacciense, but noted that he still believed that two species were included within these samples and that $H$. index was still valid even though he was uncertain how to definitively separate the samples into two distinct species. Froehlich (2002) assigned this species to Protorohippus, and we follow that designation here. It seems clear that $P$. venticolum is a highly variable species, both in size and morphology. We concur with Gazin (1962) that two species probably are represented within the various samples, but we have chosen to include all of the Fossil Butte specimens referred above in this single species given the fragmentary nature of most specimens and the difficulty in isolating trends in either size or morphology.

Measurements.-See Table 2 for tooth measurements of Protorohippus venticolum.

Genus Xenicohippus Bown and Kihm, 1981

Type species.-Xenicohippus grangeri Bown and Kihm, 1981, Bighorn Basin, Wyoming.

Xenicohippus craspedotum (Cope, 1880)

1880 Hyracotherium craspedotum Cope, p. 747

1908 Eohippus craspedotum; Granger, p. 244

1952 Hyracotherium, cf. H. venticolum (in part); Gazin, p. 66
1962 Hyracotherium, cf. H. craspedotum (in part); Gazin, p. 74 , Pl. 13, fig. 11

1966 Hyracotherium craspedotum; Robinson, p. 61, Pl. IV, fig. 3

Holotype.-AMNH 4830, left and right dentaries, Wasatchian Biochron Wa6, Wind River Formation, Wind River Basin, Wyoming.

Occurrence.-Localities FB-1, 6, 25.

Materials.-FB-1: FB 96-040, left p2. FB-6: FB 96-008, right dentary p3-m1. FB-25: FB 97-111, left dentary p3-4, late middle early Eocene, Wasatchian biochronologic zone Wa-6 (FB-6, 25) and late early Eocene, Wasatchian biochronologic zone Wa-7 (FB-1), main body, Wasatch Formation, Fossil Basin, Lincoln County, Wyoming.

Remarks.-Three equid specimens from Fossil Butte are outside the tooth size range of $H$. vasacciense ( $=P$. venticolum) as documented by Kitts (1956). They can be recognized as the larger Wa-6-Wa-7 equid species, Xenicohippus craspedotum. Gazin (1952) identified YPM-PU 16173 from near Fossil, Wyoming as Hyracotherium cf. H. venticolum. In 1962, Gazin moved this specimen into Hyracotherium cf. $H$. craspedotum a decision with which we concur. Froehlich (2002) assigned this species to Xenicohippus, and we follow that designation here.

Measurements.-FB 96-040: $\mathrm{p} 2=6.6 \times 3.4 ; \mathrm{FB} 96-008: \mathrm{p} 3=$ $6.5 \times 4.3, \mathrm{p} 4=7.4 \times 5.9, \mathrm{~m} 1=8.2 \times 6.2 ; \mathrm{FB} 97-111: \mathrm{p} 3=6.6 \times$ $3.9, \mathrm{p} 4=7.5 \times 4.9$.

Equid sp. indet.

Occurrence.-Localities FB-1, 4-9, 11, 16, 19, 27, late middle early Eocene, Wasatchian biochronologic zone Wa-6 (FB-4-9, 11, $16,19,27)$ and late early Eocene, Wasatchian biochronologic zone Wa-7 (FB-1), main body, Wasatch Formation, Fossil Basin, Lincoln County, Wyoming.

Materials.-FB-1: FB 96-028, left Mx fragment; FB 96-031, left maxilla P4; FB 96-034, left Mx; FB 96-036, postcrania; FB 96-043, postcrania; FB 96-047, left P4; FB 96-050, postcrania. FB-4: FB 97-009, right Mx fragment. FB-5: FB 96-056, postcrania; FB 96-060, right Mx. FB-6: FB 96-004, left astragalar body; FB-7: UM 108136, postcrania. FB-8: FB 96-016, tooth fragments. FB-9: FB 96-066, postcrania. FB-11: FB 96-087, postcrania; FB 96-089, left Mx; FOBU 6357, postcrania; FOBU 6364, left m3 talonid; FOBU 6450, postcrania. FB-16: FB 97035, tooth fragments; FOBU 6367, left astragalus; FOBU 6431, right mx trigonid. FB-19: FB 97-085, left dentary dp3; FB 97086, left maxilla dP3; FB 97-091, right astragalus. FB-27: FOBU 6369, left and right Mx (broken), canine fragment; FOBU 6411, postcrania.

Remarks.-These equid specimens are not complete enough for further identification. 
Table 2. Tooth measurements of Protorohippus venticolum; $\mathrm{L}=$ maximum length, $\mathrm{W}=$ maximum width, $\mathrm{d}$ indicates deciduous tooth.

\begin{tabular}{|c|c|c|c|c|c|c|c|c|c|c|c|c|c|c|c|c|c|c|c|c|c|c|c|c|}
\hline Specimen & p3L & $\mathrm{p} 3 \mathrm{~W}$ & $\mathrm{p} 4 \mathrm{~L}$ & $\mathrm{p} 4 \mathrm{~W}$ & $\mathrm{dp} 4 \mathrm{~L}$ & $\mathrm{dp} 4 \mathrm{~W}$ & $\mathrm{~m} 1 \mathrm{~L}$ & $\mathrm{~m} 1 \mathrm{~W}$ & $\mathrm{~m} 2 \mathrm{~L}$ & $\mathrm{~m} 2 \mathrm{~W}$ & $\mathrm{~m} 3 \mathrm{~L}$ & $\mathrm{~m} 3 \mathrm{~W}$ & $\mathrm{P} 2 \mathrm{~L}$ & $\mathrm{P} 2 \mathrm{~W}$ & P3L & P3W & P4L & $\mathrm{P} 4 \mathrm{~W}$ & M1L & M1W & M2L & M2W & M3L & M3W \\
\hline $\begin{array}{l}\text { FOBU } 6325 \\
\text { FOBU } 6374\end{array}$ & & & & & 60 & 30 & & & & & & & 5.3 & 3.8 & & & 6 & 7.8 & 6.9 & 8.3 & 7.8 & 9.6 & 7.9 & 9.3 \\
\hline $\begin{array}{l}\text { FOBU } 6374 \\
\text { FOBU } 6378\end{array}$ & & & 5.6 & 4.1 & 6.2 & 3.9 & 6.4 & 4.5 & $\begin{array}{l}8.1 \\
7.1\end{array}$ & $\begin{array}{l}5.6 \\
5.1\end{array}$ & 9.9 & 5 & 47 & 34 & 53 & 56 & 56 & 67 & 65 & 81 & 75 & 89 & & \\
\hline $\begin{array}{l}\text { FOBU } 6382 \\
\text { FOBU } 6383\end{array}$ & 5.4 & 3.3 & 5.4 & 3.8 & & & & & 6.6 & 4.4 & 8.7 & 4.3 & & & & & & & & & & & & \\
\hline FOBU 6387 & & & & & & & & & & & & & & & & & & & & & 7.2 & 8.6 & & \\
\hline FOBU 6404 & & & & & & & & & & & & & & & & & & & & & 7 & 8.5 & & \\
\hline FOBU 6418 & & & & & & & 6.2 & 4.5 & & & & & & & & & & & & & & & & \\
\hline $\begin{array}{l}\text { FOBU } 6428 \\
\text { FB } 95-006\end{array}$ & 5 & 3.3 & & & & & 77 & 5 & & & & & & & & & & & & & & & & \\
\hline FB 96-017 & & & & & & & & & 6.7 & 4.4 & & & & & & & & & & & & & & \\
\hline $\begin{array}{l}\text { FB 96-064 } \\
\text { FB 96-073 }\end{array}$ & & & 5.6 & 4.1 & & & & & & & & & & & & & & & & & & & & \\
\hline FB 96-074 & & & & & & & & & & & & & & & & & 5.7 & 6.2 & & & & & 7.8 & 8.3 \\
\hline FB 97-117 & & & & & & & & & & & & & & & & & & & & & & & 6.4 & 7.9 \\
\hline FB $97-025$ & & & & & & & 7.2 & 4.7 & & & & & & & & & & & & & & & & \\
\hline FB 97-027 & & & & & & & & & & & 10.6 & 5.9 & & & & & & & & & & & 7.9 & 9 \\
\hline $\begin{array}{l}\text { FB } 97-031 \\
\text { FB 97-034 }\end{array}$ & & & 58 & 39 & & & 6.7 & 4.5 & & & & & & & & & & & & & & & & \\
\hline $\begin{array}{l}\text { FB 97-034 } \\
\text { FB 97-042 }\end{array}$ & 57 & 37 & $\begin{array}{l}3.8 \\
62\end{array}$ & $\begin{array}{l}3.9 \\
4.4\end{array}$ & & & 69 & 52 & 7.7 & 54 & & & & & & & & & & & & & & \\
\hline FB 97-071 & 5.7 & 3.1 & & & & & & 5.2 & 9.1 & $\begin{array}{l}5.4 \\
5.7\end{array}$ & & & & & & & & & & & & & & \\
\hline FB 97-078 & & & & & & & 7.3 & 5 & & & & & & & & & & & & & & & & \\
\hline FB 97-084 & & & & & & & & & 8.5 & 5.4 & & & & & & & & & & & & & & \\
\hline FB 97-093 & & & & & 6.6 & 3.9 & & & 8.3 & 5.2 & & & & & & & & & & & & & & \\
\hline FB 97-103 & & & & & & & & & & & & & & & & & & & & & & & 6.5 & 8.8 \\
\hline UM 102590 & & & & & & & & & & & & & & & 5.5 & 6.8 & & & & & & & & \\
\hline UM 108137 & & & & & & & & & & & & & 4.4 & 3.5 & & & & & & & & & & \\
\hline UM 108139 & & & 5.8 & 4.2 & & & & & & & & & & & & & & & & & & & & \\
\hline UM 108140 & 5.1 & 3.4 & & & & & & & & & & & & & & & & & & & & & & \\
\hline UM 108141 & & & & & & & & & & & & & & & & & 5.8 & 6.9 & & & & & & \\
\hline
\end{tabular}


Family Helaletidae Osborn and Wortman, 1892

Genus Heptodon Cope, 1882e

Type species.—Lophiodon ventorum Cope, 1880, Wind River Basin, Wyoming.

\section{Heptodon calciculus (Cope, 1880)}

Figure 9.3

1880 Lophiodon calciculus Cope, p. 747

1952 Heptodon cf. H. ventorum (in part); Gazin, p. 70

1962 Heptodon ventorum (in part); Gazin, p. 78, Pl. 13, fig. 12

Holotype--AMNH 4858, left and right dentaries p3-m3, Wasatchian Biochron Wa7, Wind River Formation, Wind River Basin, Wyoming.

Occurrence.-Localities FB-9, 12, 26, late middle early Eocene, Wasatchian biochronologic zone Wa-6, main body, Wasatch Formation, Fossil Basin, Lincoln County, Wyoming.

Materials.-FB-9: FOBU 6179, left M1; FOBU 6291, right dP4. FB-12: FB 96-092, left M1. FB-26: FOBU 6333, left dentary $\mathrm{mx}$ fragment.

Remarks.-Heptodon is the most common tapiroid known from Wa-6-Wa-7 in Wyoming and Colorado. These specimens agree in size and morphological detail with $H$. calciculus and are smaller than Heptodon posticus (Radinsky, 1963). Gazin (1952) tentatively identified YPM-PU 16174, a dP/4 from near Fossil, Wyoming, as Heptodon ventorum. In 1962, Gazin again identified this specimen, along with four lots of fragmentary teeth from Fossil Butte (no specimen numbers cited), as H. ventorum, although he noted that all of these specimens corresponded more closely to the holotype of $H$. calciculus. We recognize all specimens of Heptodon from Fossil Butte as H. calciculus.

Measurements.-FOBU 6179: M1 = 10.9 x 12.3; FOBU 6291: $\mathrm{dP} 4=11.0 \times 11.2$.

Family Palaeotheriidae Bonaparte, 1850 Genus Lambdotherium Cope, 1880

Type species._Lambdotherium popoagicum Cope, 1880, Wind River Basin, Wyoming.

Lambdotherium popoagicum Cope, 1880 Figure 9.4

Holotype--AMNH 4863, left dentary p2-m3, Wasatchian Biochron Wa7, Wind River Formation, Wind River Basin, Wyoming.

Occurrence.-Locality FB-1, late early Eocene, Wasatchian biochronologic zone Wa-7 (FB-1), main body, Wasatch Formation, Fossil Basin, Lincoln County, Wyoming.

Materials.-FOBU 6154, left $\mathrm{m} 1$ trigonid.
Remarks.-Although this specimen is fragmentary, it can be confidently identified as Lambdotherium. Lambdotherium is the primary index taxon of the Lostcabinian, indicating that the top of the Wasatch section at Fossil Butte represents Wa-7.

Order Artiodactyla Owen, 1848

Family Dichobunidae Turner, 1849

Genus Bunophorus Sinclair, 1914

Type species.-Mioclaenus etsagicus Cope, 1882a, Bighorn Basin, Wyoming.

\section{Bunophorus grangeri (Sinclair, 1914)}

Figure 10.1-10.2

1914 Wasatchia grangeri Sinclair, p. 269

Holotype.-AMNH 15516, left and right dentaries, Gray Bull beds, middle Wasatchian (Wa3-5), Willwood Formation, Bighorn Basin, Wyoming.

Occurrence.-Localities FB-11, 13, 16, 19, 27, late middle early Eocene, Wasatchian biochronologic zone Wa-6, main body, Wasatch Formation, Fossil Basin, Lincoln County, Wyoming.

Materials.-FB-11: FOBU 6394, left $\mathrm{m} 2$ fragment. FB-16: FOBU 6280, left $\mathrm{m} 2$ fragment, M/3. FB-19: FOBU 6441, left P3. FB-27: FOBU 6410, right M1. Also FOBU 6194, a right dentary fragment with $\mathrm{c} 1$ from $\mathbf{F B}-13$ is questionably assigned to Bunophorus.

Remarks.-These specimens represent a relatively small species of Bunophorus. They agree in size and morphology with B. grangeri (Stucky and Krishtalka, 1990).

Measurements.-FOBU 6410: M1 = 5.8 x 6.8; FOBU 6441: $\mathrm{P} 3=5.4 \times 4.6$.

Genus Diacodexis Cope, 1882e

Type species.-Pantolestes secans Cope, 1881, Wind River Basin, Wyoming.

Diacodexis secans (Cope, 1881)

Figure 10.3

1881 Pantolestes secans Cope, p. 187

Holotype.-AMNH 4899, left and right dentaries p4-m3, Wasatchian Biochron Wa6, Wind River Formation, Wind River Basin, Wyoming.

Occurrence.—Localities FB-1, 5, 16, 19, 27, late middle early Eocene, Wasatchian biochronologic zone Wa-6 (FB-5, 16, $19,27)$ and late early Eocene, Wasatchian biochronologic zone Wa-7 (FB-1), main body, Wasatch Formation, Fossil Basin, Lincoln County, Wyoming. 


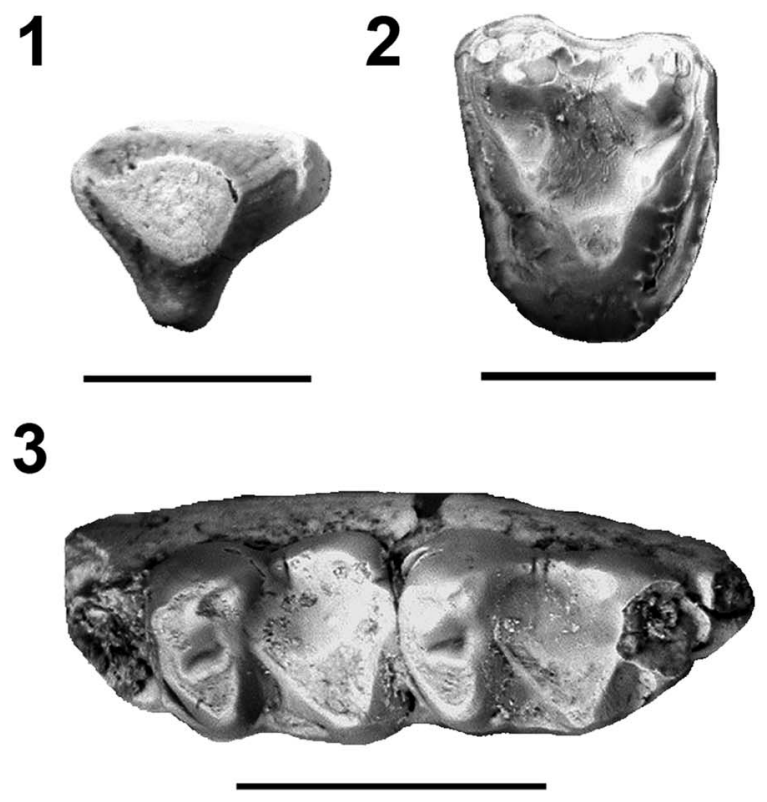

4
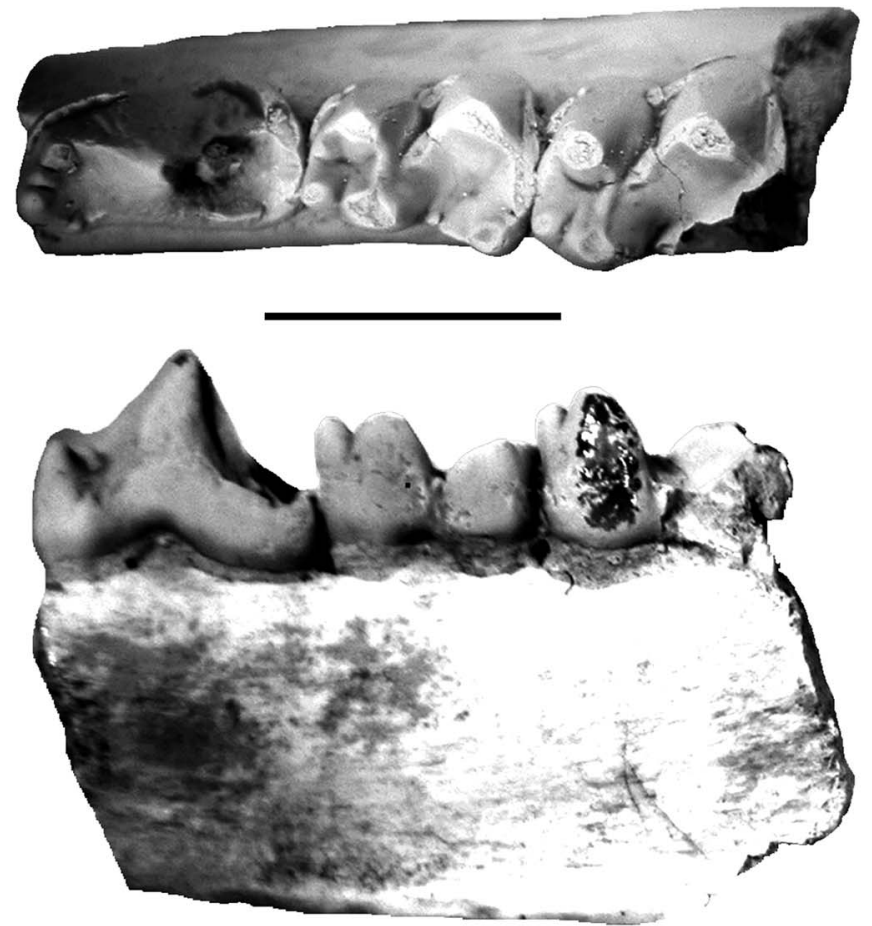

Figure 10. (1) FOBU 6441, Bunophorus grangeri, left P3 in occlusal view. (2) FOBU 6410, Bunophorus grangeri, right M1 in occlusal view. (3) FOBU 6122, Diacodexis secans, left dentary m2-3 in occlusal view. (4) FOBU 6123, Hexacodus uintensis, right dentary $\mathrm{p} 4-\mathrm{m} 2$ in occlusal (top) and lingual (bottom) views. Scale bars $=5 \mathrm{~mm}$.

Materials.-FB-1: FOBU 6182, left mx trigonid. FB-5: FOBU 6421, left M1. FB-16: FOBU 6122, left dentary m2-3; FOBU 6226, right dentary m3; FOBU 6279, left M1; FOBU 6432, left Mx (worn); FOBU 6447, left dentary $\mathrm{m} 1$ fragment. FB-19: FOBU 6416, left m1; FOBU 6446, right M3. FB-27: FOBU 6337, left M1.
Remarks.-Diacodexis secans is the most common dichobunid artiodactyl known in Wa-6-Wa-7 (Krishtalka and Stucky, 1985). These specimens agree in size and morphology with this species.

Measurements.-FOBU 6122: $\mathrm{m} 2=4.2$ x 3.5; FOBU 6279: $\mathrm{M} 1=4.1 \times 4.9 ;$ FOBU 6337: $\mathrm{M} 1=4.2 \times 5.2 ;$ FOBU 6416: $\mathrm{m} 1=4.2 \times 3.5 ;$ FOBU 6421: $\mathrm{M} 1=4.3 \times 5.3 ;$ FOBU 6446: $\mathrm{M} 3=3.4 \times 5.1$.

Family Homacodontidae Marsh, 1894 Genus Hexacodus Gazin, 1952

Type species.-Hexacodus pelodes Gazin, 1952, Green River Basin, Wyoming.

\section{Hexacodus uintensis Gazin, 1952}

Figure 10.4

1952 Hexacodus uintensis Gazin, p. 76, Pl. 11, fig. 4

1962 Hexacodus uintensis, Gazin, p. 85, Pl. 14, fig. 5

Holotype.-USNM 16175, left dentary m1-2, Wasatchian Biochron Wa6, Wasatch Formation, Green River Basin, 3 miles NW of Fossil Station, Wyoming.

Occurrence.-Localities FB-11, 16, 19, 24, 27, late middle early Eocene, Wasatchian biochronologic zone Wa-6, main body, Wasatch Formation, Fossil Basin, Lincoln County, Wyoming.

Materials.-FB-11: FOBU 6449, right dentary $\mathrm{m} 1$ talonid-m2. FB-16: FOBU 6228, left M1. FB-19: FOBU 6123, right dentary p4-m2. FB-24: FOBU 6327, left maxilla M1. FB-27: FOBU 6402, right $\mathrm{mx}$ (broken).

Remarks.-Hexacodus uintensis was described by Gazin (1952) based on a single specimen (YPM-PU 16175) from three miles northwest of Fossil, Wyoming. Gazin (1962) later described another specimen of $H$. uintensis (USNM 22250) from Fossil Butte and noted that two other specimens, one from Knight Station and the other from the Bighorn Basin, might represent this species as well. The specimens assigned here expand the sample of this rare artiodactyl.

FOBU 6123 includes the first p4 known for H. uintensis. It differs from $\mathrm{p} 4$ in $H$. pelodes in being laterally compressed anteriorly, with the talonid being broader than the anterior part of the tooth. It also has a stronger paracristid that developed a small accessory cuspule close to the anterior flank of the protoconid unlike $H$. pelodes. The p4 of $H$. uintensis has a small anterobuccal cingulid, which is lacking in $H$. pelodes. Unlike that species, the p4 of $H$. uintensis lacks an entoconid cusp.

Measurements.-FOBU 6449: $\mathrm{m} 2=4.4$ x 3.6; FOBU 6228: $\mathrm{M} 1=4.2 \times 5.1 ;$ FOBU 6123: $\mathrm{p} 4=4.9 \times 2.7, \mathrm{~m} 1=4.4 \times 3.1$; FOBU 6327: $\mathrm{M} 1=4.6 \times 5.6$. 


\section{Faunal comparisons, paleoecology and age}

The mammalian assemblage from the Wasatch Formation at Fossil Butte (Table 1) presents interesting similarities and contrasts with other Wa-6 and Wa-7 samples from Wyoming. Figure 11.1 compares diversity as expressed by species per order between the Fossil Butte sample, a Wa-6 sample from the Bighorn Basin in northwestern Wyoming (UM collections), and a Wa-7 sample from the Pinnacles area of the northeastern Green River Basin, southwestern Wyoming (Gunnell et al., 2004; UM collections). Although a limited Wa-7 fauna occurs $30 \mathrm{~km}$ to the southeast, on Little Muddy Creek near the hamlet of Cumberland Gap (Zonneveld et al., 2000), this fauna is too limited, in both diversity and abundance to facilitate useful comparison to the Fossil Butte material.

The Fossil Butte sample is similar to the Wa-6 sample in having relatively high diversity of Cimolesta, Condylarthra, and Carnivora, but differs in having a lower diversity of Primates, "Creodonta", and Perissodactyla, and a much higher diversity of Rodentia. In comparison to the Wa-7 sample, Fossil Butte exhibits higher diversity of Cimolesta, Condylarthra, Rodentia, and Carnivora, but lower diversity of Primates and Perissodactyla. Perhaps the most unusual aspect of Fossil Butte mammalian diversity is the relatively low diversities of primates and perissodactyls (especially given the high abundance of perissodactyls, see below) and the very high diversity of rodents.

Relative abundances of Fossil Butte mammals can be compared to assemblages from the Bighorn Basin and the Pinnacles in northwestern and southwestern Wyoming, respectively. Since sample size for the Fossil Butte assemblage is relatively low, these comparisons will be made using percent of specimens in each sample. Figure 11.2 compares relative abundance for eight orders of Fossil Butte mammals with assemblages from the Bighorn Basin and the Pinnacles. Compared to Fossil Butte, both the Bighorn Basin and Pinnacles samples have higher abundances of condylarthans, almost entirely due to the very high abundance of Hyopsodus in the latter two basins. While relatively common at Fossil Butte, Hyopsodus only represents $14 \%$ of the mammalian sample compared to $21.5 \%$ in the Bighorn Basin and $22.3 \%$ at the Pinnacles. Both of these samples also have higher abundances of plesiadapiforms compared to Fossil Butte, almost entirely represented by Microsyops.

In contrast to the Bighorn and Pinnacles samples, perissodactyls are more common at Fossil Butte, almost entirely due to the high abundance of equids. At Fossil Butte, Xenicohippus and Protorohippus account for $32.7 \%$ of all mammal specimens, while in the Bighorn Basin the relative abundance of equids is at $23 \%$ and $17.6 \%$ at the Pinnacles.

Primates exhibit similar specimen abundance in all three samples, but there are substantial differences in the taxonomic composition of primates among the three areas. Primate taxonomic composition at Fossil Butte consists entirely of notharctid primates - there are no omomyid primates yet known from any Fossil Butte locality. Omomyids make up $36 \%$ of all primate specimens from Wa-6 localities in the Bighorn Basin and 26.7\% of Wa-7 primate specimens from the Pinnacles.
The apparent absence of omomyid primates at Fossil Butte is probably at least partly because of the relatively poor preservation in the Wasatch Formation locally. Specimens are fragmentary with few documented associations. There are no vertebrate bone concentrations and screen washing for smaller members of the vertebrate community has proven unproductive. Omomyids are all relatively small and are difficult to find by surface prospecting. However, paleoecological factors also may be partially responsible for the lack of Fossil Basin omomyids.

Early Eocene (Wasatchian) omomyid primates from both the Fossil and greater Green River basins are extremely rare. Outside of a single series of localities in the Washakie Basin (Savage and Waters, 1978), published records of omomyids from the rest of the early Eocene of southwestern Wyoming consist of fewer than 75 specimens (Gazin, 1952, 1958, 1962; West, 1973; Szalay, 1976; Stucky, 1984; Bown and Rose, 1987; Zonneveld et al., 2000; Muldoon and Gunnell, 2002; Holroyd and Strait, 2008; Nachman et al., 2010). The paucity of omomyids from early Eocene strata in the greater Green River Basin suggests that ecological conditions were not suitable for anaptomorphine omomyids, the subfamily most common in the Wasatchian (Gunnell, 1997). However, by the middle Eocene (Bridgerian biochrons Br1b-Br3), omomyine omomyids are common elements in mammalian faunal assemblages of the Bridger Formation in the Green River Basin.

Overall, mammalian faunal community structure at Fossil Butte, combined with geological evidence, suggests paleohabitats consisting of both forested and more open areas. The extremely high abundance of the equid perissodactyls Protorohippus and Xenicohippus argue for open, broken forest habitats. The modestly high abundance of artiodactyls also suggests the presence of some open habitats. The relatively high abundance of notharctine primates indicates that forested areas occurred nearby, perhaps along river and stream courses.

The abundant presence of hydromorphic paleosols (sensu Kraus and Aslan, 1993) at the base of the exposed main body of the Wasatch Formation at Fossil Butte suggests that the lower portion of the section was deposited during relatively wet and poorly drained conditions. The middle part of the section (with better developed paleosols) was probably deposited during an interval with better drainage deposition. The upper part of the section was deposited under more poorly drained conditions and was followed by the onset of lake-sediment deposition as Fossil Lake formed during the Lostcabinian (Grande, 1984, 2013; Lillegraven and Ostresh, 1988).

Differences between the mammalian faunal sample at Fossil Butte and those in other areas are almost certainly due to the differing paleoecological condition. The fact that Fossil Basin was geomorphically isolated from other areas to the east by the Wyoming Overthrust Belt and to the west by the Tunp Range, may have contributed to some of the unusual occurrences in the Fossil Butte sample. The presence of Knightomys huerfanensis, Copelemur tutus, and Reithroparamys debequensis, all more common from southern areas (Colorado and New Mexico), suggests some interchange between Fossil Basin and these southern communities. Meniscotherium, which is common in both New Mexico and the adjacent Green River Basin, is nearly absent from Fossil Basin, suggesting that 

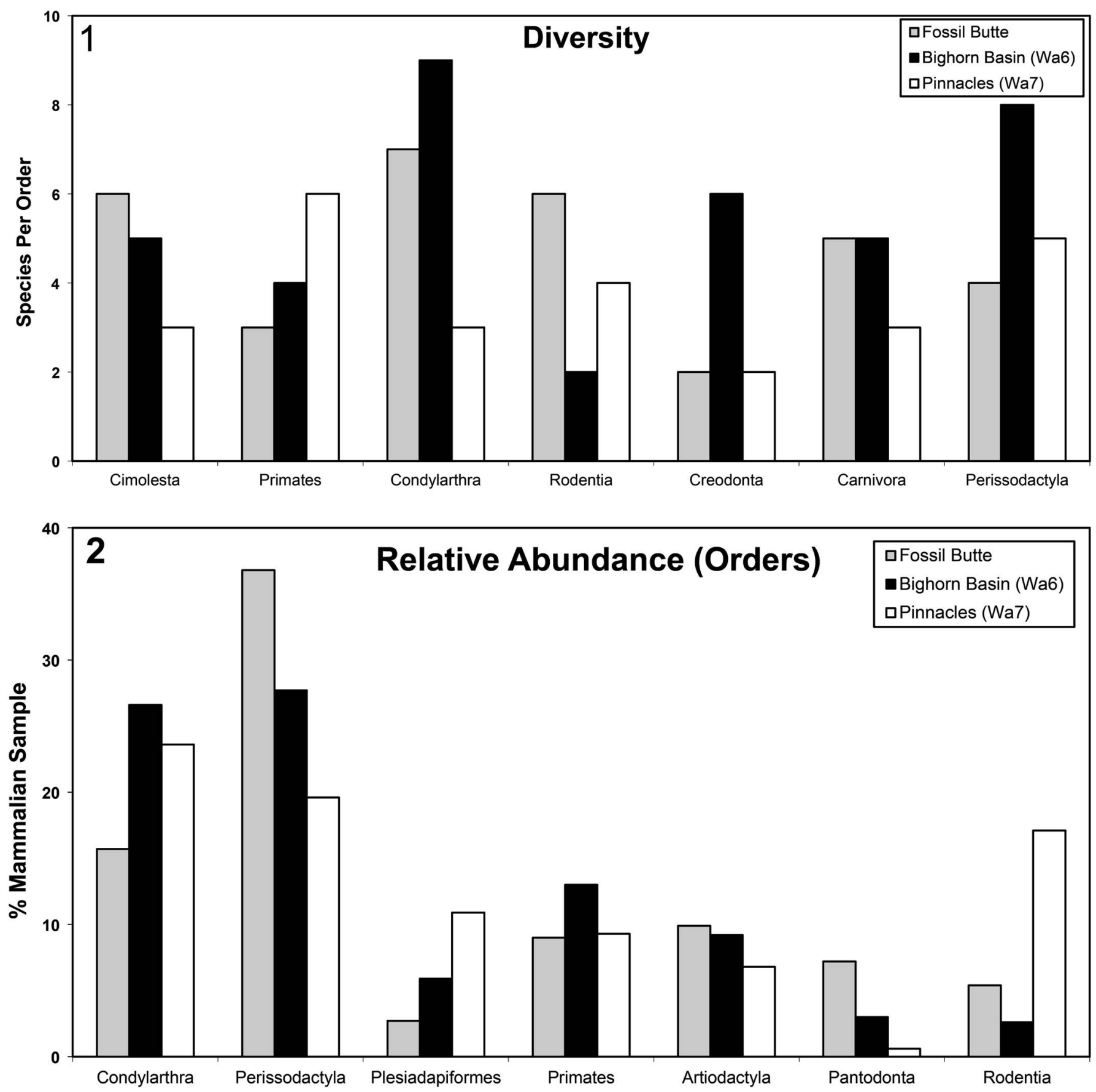

Figure 11. (1) Mammalian species-level diversity (number of species per selected orders) at Fossil Butte compared to a Wa-6 sample from the Bighorn Basin in northwestern Wyoming and a Wa-7 sample from the Pinnacles area near South Pass, southwestern Wyoming. (2) Mammalian abundance (percent total number of specimens representing selected orders) at Fossil Butte compared with same faunal samples as in 1.

Meniscotherium preferred habitats different from those available in the Fossil Basin.

Given the location of Fossil Basin within the Overthrust Belt, it might be expected that the sample would include faunal indications of basin-margin habitats (Gunnell and Bartels, 2001). Included among basin-margin faunal indicators are the presence of unique species, such as the rodent Adaetoparamys blochi, the artiodactyl Hexacodus uintensis, the leptictid Eoictops novaceki, and the pantolestid Palaeosinopa lacus. The occurrences of the rare Wa-6 taxa Apheliscus and Haplomylus, and the anachronistically early appearance of the very rare Ectocion superstes may also suggest basin-margin influences.

Figure 12 summarizes the stratigraphic ranges of mammalian taxa in the Fossil Butte Wasatch Formation sequence. The Wa6 index taxon Heptodon calciculus is first found $135 \mathrm{~m}$ below the base of the Fossil Butte Member of the Green River Formation at locality FB-26. There is only one locality (FB-6) below the level of FB-26 that has yielded any identifiable mammals. None of the taxa recovered from this level suggests any pre-Wa-6 Eocene horizons existing at Fossil Butte. 


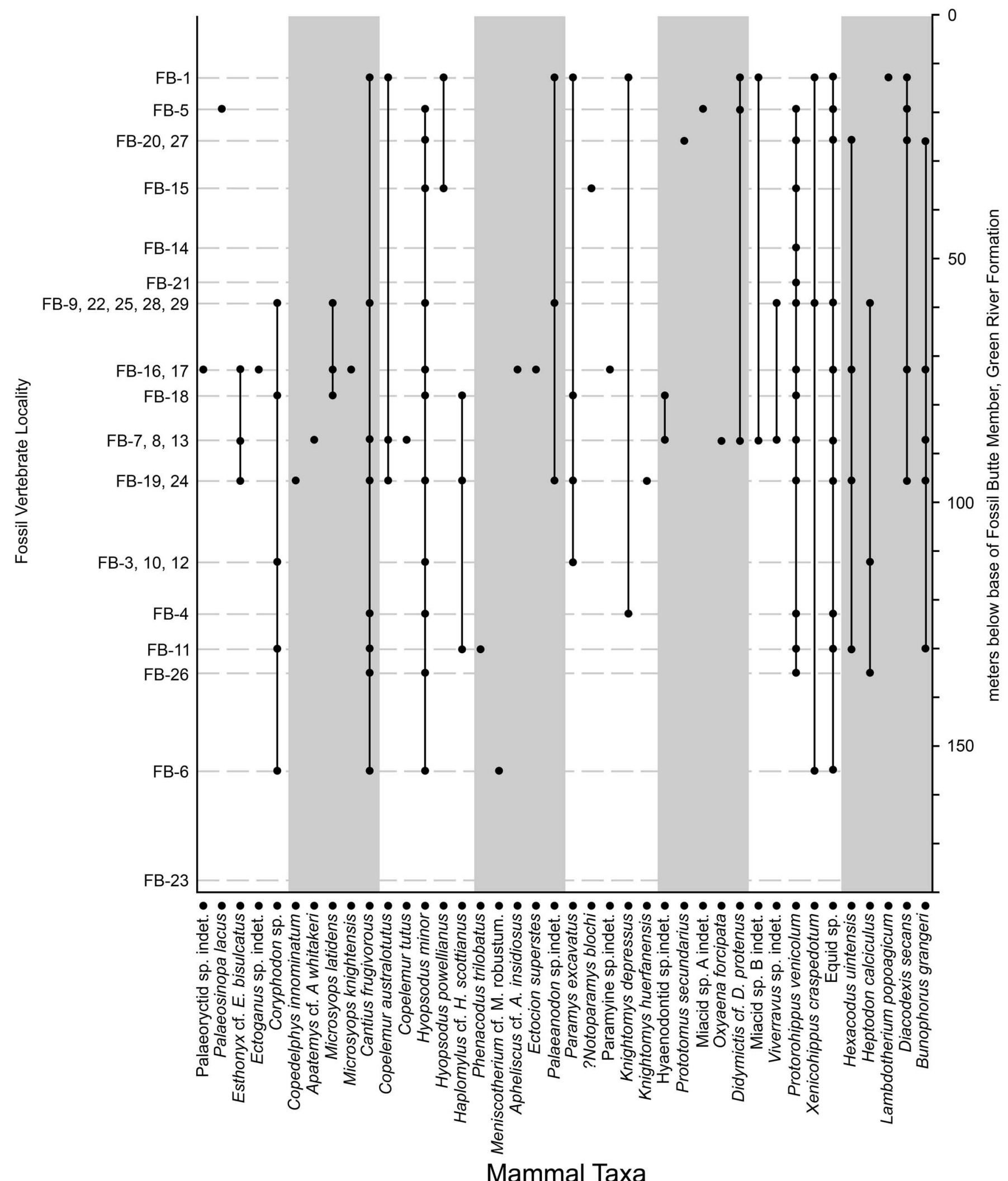

Figure 12. Stratigraphic ranges of mammalian taxa in the Wasatch Formation at Fossil Butte, not including specimens found previous to this work (Mesonychid indet., Reithroparamys cf. R. debequensis, Vulpavus australis) because it was not possible to precisely fit them into proper stratigraphic position. Left axis shows the distribution of fossil localities in the Fossil Butte section. Right axis shows section measured in $\mathrm{m}$ below the base of the overlying Fossil Butte Member of the Green River Formation. 
Lambdotherium appears at locality FB-1, within $15 \mathrm{~m}$ of the base of the Fossil Butte Member of the Green River Formation. This indicates that the top of the Fossil Butte section of the Wasatch Formation represents the Lostcabinian (Wa-7), as does the Fossil Butte Member of the Green River Formation, wherein Lambdotherium has also been found (Froehlich and Breithaupt, 1997). Based on the ranges of mammalian taxa at Fossil Butte, all of the Wasatch Formation represents at least $\mathrm{Wa}-6$, with the top $15 \mathrm{~m}$ of the section representing $\mathrm{Wa}-7$.

\section{Summary}

The mammalian faunal assemblage from the Wasatch Formation at Fossil Butte National Monument consists of 36 genera and as many as 46 species. Two genera and three species are new and, along with Hexacodus uintensis, are unique to the Fossil Butte sample. Most of the other members of the assemblage are well known from other Wa-6 sediments in Wyoming and New Mexico. The top $15 \mathrm{~m}$ of the local section samples the beginning of the succeeding Wasatchian biochron (Wa-7), as indicated by the first appearance of the immigrant perissodactyl Lambdotherium. However, some taxa represent relatively rare forms (Ectocion superstes) or unusually late Wasatchian occurrences (Apheliscus, Haplomylus), suggesting that Fossil Basin may have provided a refugium for some taxa. Also, some taxa are more common from southern basins within North America (Knightomys huerfanensis, Copelemur tutus, and Reithroparamys debequensis), indicating that Fossil Basin exchanged faunal elements with these areas during the early Eocene. The most abundant mammals living in Fossil Basin during Wa-6 were equid perissodactyls representing over $30 \%$ of the total number of specimens. The relatively high percentage occurrence of fossil horses at Fossil Butte suggests that welldrained, open-forest habitats were common in the area during the early Eocene.

\section{Acknowledgments}

The authors thank A.L. Brandes, K.M. Christenson, J.M. Lavigne, S. Zack, R.J. Walker, J.I. Bloch, and A.R. Bair for their work in describing and measuring the stratigraphic sections and fossil collecting. We thank R.L. Anemone for providing access to unpublished data from the southern Red Desert. We also thank the staff at Fossil Butte National Monument, especially Superintendent D. McGinnis, R. Benton, P. Ambrose, V. Santucci, and A. Aase, for their assistance during our work. We thank J.A. Lillegraven, J.E. Storer, D. Anderson, and the late S.L. Walsh for many helpful comments on previous versions of this manuscript. This research was supported by National Park Service and NSF grants to WSB and GFG and an NSERC Discovery grant to JPZ.

\section{References}

Alston, E.R., 1876, On the classification of the order Glires: Proceedings of the Zoological Society of London, v. 1876, p. 61-98.

Anderson, D., 2008, Ischyromyidae, in Janis, C.M., Gunnell, G.F., and Uhen, M.D., eds., Evolution of Tertiary Mammals of North America, Volume 2: Cambridge, Cambridge University Press, p. 311-325.
Beard, K.C., 1988, New notharctine primate fossils from the early Eocene of New Mexico and southern Wyoming and the phylogeny of Notharctinae: American Journal of Physical Anthropology, v. 75, p. 439-469.

Bloch, J.I., Secord, R., and Gingerich, P.D., 2004, Systematics and phylogeny of late Paleocene and early Eocene Palaeoryctinae (Mammalia, Insectivora) from the Clarks Fork and Bighorn Basins, Wyoming: Contributions from the Museum of Paleontology, University of Michigan, v. 31, p. 119-154.

Bonaparte, C.L., 1850, 1. Conspectus Systematis Mastozoologiae. Editio altera reformata, Leiden, Conspectus Systematum, 372 p.

Bowdich, T.E., 1821, An Analysis of the Natural Classifications of Mammalia for the use of Students and Travelers, Paris, J. Smith, 115 p.

Bown, T.M., and Kihm, A.J., 1981, Xenicohippus, an unusual new hyracothere (Mammalia, Perissodactyla) from the lower Eocene rocks of Wyoming, Colorado and New Mexico: Journal of Paleontology, v. 55, p. 257-270.

Bown, T.M., and Rose, K.D., 1987, Patterns of dental evolution in early Eocene anaptomorphine primates (Omomyidae) from the Bighorn Basin, Wyoming: The Paleontological Society Memoir, v. 23, p. 1-151.

Buchheim, H.P., 1994, Paleoenvironments, lithofacies and varves of the Fossil Butte Member of the Eocene Green River Formation, southwestern Wyoming: Contributions to Geology, University of Wyoming, v. 3, p. 3-14.

Buchheim, H.P., and Eugster, H.P., 1998, Eocene Fossil Lake: the Green River Formation of Fossil Basin, southwestern Wyoming: Utah Geological Association Publication, v. 26, p. 191-208.

Buchheim, H.P., Cushman, R.A. Jr., and Biaggi, R.E., 2011, Stratigraphic revision of the Green River Formation in Fossil Basin, Wyoming: Overfilled to underfilled lake evolution: Rocky Mountain Geology, v. 46, p. 165-181.

Cooper, C.F., 1932, On some mammalian remains from the Lower Eocene of the London Clay: Annals and Magazine of Natural History, London, v. 1901, p. 129-153.

Cope, E.D., 1872, Third account of new Vertebrata from the Bridger Eocene of Wyoming Territory: Paleontological Bulletin, v. 3, p. 1-4.

Cope, E.D., 1873, Fourth notice of extinct Vertebrata from the Bridger and Green River Tertiaries: Paleontological Bulletin, v. 17, p. 1-4.

Cope, E.D., 1874, Report upon vertebrate fossils discovered in New Mexico with descriptions of new species: Geographical Exploration and Survey West of the $100^{\text {th }}$ Meridian, Appendix FF, Chief of Engineers for 1874, Washington, D.C., p. 1-18.

Cope, E.D., 1875, Systematic catalogue of Vertebrata of the Eocene of New Mexico, collected in 1874: Report to Engineer Department, U. S. Army (Wheeler Survey), Washington, D.C., p. 5-37.

Cope, E.D., 1876, On the Taeniodonta, a new group of Eocene Mammalia: Proceedings of the Academy of Natural Sciences, Philadelphia, v. 28, p. 39.

Cope, E.D., 1877, Report upon the extinct Vertebrata obtained in New Mexico by parties of the expedition of 1874: Chapter XII, Fossils of the Eocene period: Geographical Surveys West of the $100^{\text {th }}$ Meridian, Corps of Engineers (Wheeler Survey), U. S. Army, Washington, D.C., p. 37-282.

Cope, E.D., 1880, The bad lands of the Wind River and their fauna: The American Naturalist, v. 14, p. 745-748.

Cope, E.D., 1881, On the Vertebrata of the Wind River Eocene beds of Wyoming: Bulletin of the U. S. Geological and Geographical Survey of the Territories, v. 6, p. 183-202.

Cope, E.D., 1882a, Contributions to the history of the Vertebrata of the lower Eocene of Wyoming and New Mexico made in 1881. I. The fauna of the Wasatch beds of the Basin of the Big Horn River: Proceedings of the American Philosophical Society, v. 20, p. 139-197.

Cope, E.D., 1882b, On the Vertebrata of the Wind River Eocene Beds of Wyoming: Bulletin of the U. S. Geographical and Geological Survey of the Territories, v. 6, p. 183-202.

Cope, E.D., 1882c, Notes on Eocene Mammalia: The American Naturalist, v. 16, p. 522 .

Cope, E.D., 1882d, New characters of the Perissodactyla Condylartha: The American Naturalist, v. 16, p. 334

Cope, E.D., 1882e, Two new genera of Mammalia from the Wasatch Eocene: The American Naturalist, v. 16, p. 1029.

Cope, E.D., 1883, On the mutual relations of the bunotherian Mammalia: Proceedings of the Academy of Natural Sciences, Philadelphia, v. 1883, p. $77-83$.

Cope, E.D., 1884, The Vertebrata of the Tertiary formations of the west: Book I: Report to the U.S. Geological Survey of the Territories (Hayden Survey), v. 3, p. 1-1009.

Crochet, J.-Y., 1979, Données nouvelles sur l'histoire paléogéographique des Didelphidae (Marsupialia): Comptes Rendus de l'Academie des Sciences, Paris, v. 288, p. 1457-1460.

Froehlich, D.J., 2002, Quo vadis Eohippus? The systematics and taxonomy of the early Eocene equids (Perissodactyla): Zoological Journal of the Linnean Society, v. 134, p. 141-256.

Froehlich, D.J., and Breithaupt, B.H., 1997, A Lambdotherium specimen from the Fossil Butte Member of the Green River Formation, with comments on 
its biostratigraphic and paleoenvironmental importance and the phylogenetic significance of its postcrania: Journal of Vertebrate Paleontology, Abstracts, Supplement to v, v. 17, p. 47A

Gazin, C.L., 1952, The lower Eocene Knight Formation of western Wyoming and its mammalian faunas: Smithsonian Miscellaneous Collections, v. 117, p. $1-82$.

Gazin, C.L., 1958, A review of the middle and upper Eocene primates of North America: Smithsonian Miscellaneous Collections, v. 136, p. 1-112.

Gazin, C.L., 1961, New sciuravid rodents from the lower Eocene Knight Formation of western Wyoming: Proceedings of the Biological Society of Washington, v. 74, p. 193-194.

Gazin, C.L., 1962, A further study of the lower Eocene mammalian faunas of southwestern Wyoming: Smithsonian Miscellaneous Collections, v. 144, p. $1-98$.

Gazin, C.L., 1968, A study of the Eocene condylarthran mammal Hyopsodus: Smithsonian Miscellaneous Collections, v. 153, p. 1-90.

Gill, T., 1872, Arrangement of the families of mammals with analytical tables: Smithsonian Miscellaneous Collections, v. 2, p. 1-98.

Gingerich, P.D., 1994, New species of Apheliscus, Haplomylus, and Hyopsodus (Mammalia, Condylarthra) from the late Paleocene of southern Montana and early Eocene of northwestern Wyoming: Contributions from the Museum of Paleontology, University of Michigan, v. 29, p. 119-134.

Gingerich, P.D., 2001, Biostratigraphy of the continental Paleocene-Eocene boundary interval on Polecat Bench in the northern Bighorn Basin, in Gingerich, P.D., ed., Paleocene-Eocene Stratigraphy and Biotic Change in the Bighorn and Clarks Fork Basins, Wyoming, University of Michigan, Papers on Paleontology, v. 33, p. 37-71.

Gingerich, P.D., and Simons, E.L., 1977, Systematics, phylogeny, and evolution of early Eocene Adapidae (Mammalia, Primates) in North America: Contributions from the Museum of Paleontology, University of Michigan, v. 24, p. $245-279$.

Grande, L., 1984, Paleontology of the Green River Formation, with a review of the fish fauna: The Geological Survey of Wyoming, Bulletin, v. 63, p. $1-333$.

Grande, L., 2001, An updated review of the fish faunas from the Green River Formation, the world's most productive freshwater Lagerstätten, in Gunnell, G.F., ed., Eocene Biodiversity-Unusual Occurrences and Rarely Sampled Habitats, New York, Kluwer Academic/Plenum Publishers, p. $1-38$.

Grande, L., 2013, The Lost World of Fossil Lake-Snapshots from Deep Time, Chicago, The University of Chicago Press, $425 \mathrm{p}$.

Grande, L., and Bemis, W.E., 1998, A comprehensive phylogenetic study of amiid fishes (Amiidae) based on comparative skeletal anatomy. An empirical search for interconnected patterns of natural history: Society of Vertebrate Paleontology, Memoir 4 (Supplement to v. 18), p. 1-690.

Granger, W., 1908, A revision of the American Eocene horses: Bulletin of the American Museum of Natural History, v. 24, p. 221-264.

Granger, W., 1915, A revision of the lower Eocene Wasatch and Wind River faunas. Part III. Order Condylarthra. Families Phenacodontidae and Meniscotheriidae: Bulletin of the American Museum of Natural History, v. 34 , p. $329-361$.

Gray, J. E., 1821, On the natural arrangement of vertebrose animals: London Medical Repository, v. 15, p. 296-310.

Gunnell, G.F., 1989, Evolutionary history of Microsyopoidea (Mammalia, ?Primates) and the relationship between Plesiadapiformes and Primates: Papers on Paleontology, University of Michigan, v. 27, p. 1-157.

Gunnell, G.F., 1997, Wasatchian-Bridgerian (Eocene) paleoecology of the western interior of North America: changing paleoenvironments and taxonomic composition of omomyid (Tarsiiform) primates: Journal of Human Evolution, v. 32, p. 105-132.

Gunnell, G.F., 2002, Notharctine primates (Adapiformes) from the early to middle Eocene (Wasatchian-Bridgerian) of Wyoming: transitional species and the origins of Notharctus and Smilodectes: Journal of Human Evolution, v. 43, p. 353-380.

Gunnell, G.F., and Bartels, W.S., 2001, Basin margins, biodiversity, evolutionary innovation, and the origin of new taxa, in Gunnell, G.F., ed., Eocene Biodiversity-Unusual Occurrences and Rarely Sampled Habitats, New York, Kluwer Academic/Plenum Publishers, p. 404-432.

Gunnell, G.F., Bartels, W.S., and Zonneveld, J.-P., 2004, A late Wasatchian (late early Eocene) vertebrate assemblage preserved in meandering stream channel deposits, northern Red Desert, Wyoming: Geological Society of America, Abstracts with Programs, v. 36, no. 5, p. 92.

Gunnell, G.F., Bown, T.M., Bloch, J.I., and Boyer, D.M., 2008a, "Proteutheria", in Janis, C.M., Gunnell, G.F., and Uhen, M.D., eds., Evolution of Tertiary Mammals of North America, Volume 2: Cambridge, Cambridge University Press, p. 63-81.

Gunnell, G.F., Bown, T.M., and Bloch, J.I., 2008b, Leptictida, in Janis, C.M., Gunnell, G.F., and Uhen, M.D., eds., Evolution of Tertiary Mammals of North America, Volume 2: Cambridge, Cambridge University Press, p. 82-88.
Gunnell, G.F., Bown, T.M., Hutchison, J.H., and Bloch, J.I., 2008c, Lipotyphla, in Janis, C.M., Gunnell, G.F., and Uhen, M.D., eds., Evolution of Tertiary Mammals of North America, Volume 2, Cambridge, Cambridge University Press, p. 89-125.

Gunnell, G.F., Murphey, P.C., Stucky, R.K., Townsend, K.E.B., Robinson, P., Zonneveld, J.-P., and Bartels, W.S., 2009, Biostratigraphy and biochronology of the latest Wasatchian, Bridgerian, and Uintan North American Land Mammal "Ages", in Albright, L.B., III, ed., Papers on Geology, Vertebrate Paleontology, and Biostratigraphy in Honor of Michael O. Woodburne: Museum of Northern Arizona Bulletin, v. 65, p. 279-330.

Guthrie, D.A., 1967, The mammalian fauna of the Lysite Member, Wind River Formation (early Eocene) of Wyoming: Memoirs of the Southern California Academy of Sciences, v. 5, p. 1-53.

Haeckel, E., 1895, Systematische Phylogenie der Wirbelthiere (Vertebrata), Berlin, Dritter Theil des Entwurfs einer systematischen Phylogenie, 660 p.

Hayden, F.V., 1869, Preliminary field report of the United States Geological Survey of Colorado and New Mexico. 3, p. 1-144.

Hayden, F.V., 1871, Preliminary report of the United States Geological Survey of Wyoming: United States Geological and Geographical Survey of the Territories $4^{\text {th }}$ Annual Report, v. 1871, p. 142-144.

Holroyd, P.A., and Strait, S.G., 2008, New data on Loveina (Primates: Omomyidae) from the early Eocene Wasatch Formation and Implications for washakiin relationships, in Fleagle, J.G., and Gilbert, C.C., eds., Elwyn Simons, A Search for Origins, New York, Springer, p. 243-257.

Jepsen, G.L., 1930, New vertebrate fossils from the lower Eocene of the Bighorn Basin, Wyoming: Proceedings of the American Philosophical Society, v. 64 , p. $117-130$.

Kitts, D.B., 1956, American Hyracotherium (Perissodactyla, Equidae): Bulletin of the American Museum of Natural History, v. 110, p. 1-60.

Korth, W.W., 1984, Earliest Tertiary evolution and radiation of rodents in North America: Bulletin of Carnegie Museum of Natural History, v. 24, p. 1-71.

Korth, W.W., 1994a, Middle Tertiary marsupials (Mammalia) from North America: Journal of Paleontology, v. 68, p. 376-397.

Korth, W.W., 1994b, The Tertiary Record of Rodents in North America, New York, Plenum Press, $319 \mathrm{p}$.

Korth, W.W., 2008, Marsupialia, in Janis, C.M., Gunnell, G.F., and Uhen, M.D., eds., Evolution of Tertiary Mammals of North America, Volume 2. Cambridge, Cambridge University Press, p. 39-47.

Kraus, M.J., and Aslan, A., 1993, Eocene hydromorphic paleosols: significance for interpreting ancient floodplain processes: Journal of Sedimentary Petrology, v. 63, p. 453-463.

Krishtalka, L., and Stucky, R.K., 1985, Revision of the Wind River faunas, early Eocene of central Wyoming. Part 7. Revision of Diacodexis (Mammalia, Artiodactyla): Annals of Carnegie Museum, v. 54, p. 413-486.

Leidy, J., 1856, Notice of some remains of fishes discovered by Dr. John E. Evans: Proceedings of the Academy of Natural Sciences, Philadelphia, v. 6, p. $256-257$.

Leidy, J., 1870, Report on the vertebrate fossils of the Tertiary Formations of the west: U. S. Geological Survey of the Territories (Hayden Expedition), v. 1870 , p. $340-370$.

Leidy, J., 1871, Notice of some extinct rodents: Proceedings of the Academy of Natural Sciences, Philadelphia, v. 22, p. 230-232.

Leidy, J., 1872, On the fossil vertebrates in the early Tertiary formations of Wyoming: U.S. Geological Survey of Montana and Adjacent Territories (Hayden Survey), 5th Annual Report, Washington DC, US Government Printing Office, v. 5, p. 353-377.

Lillegraven, J.A., and Ostresh, L.M. Jr., 1988, Evolution of Wyoming's early Cenozoic topography and drainage patterns: National Geographic Research, v. 4 , p. $303-327$.

Linnaeus, C., 1758, Systema Naturae, Volume I, 10th Edition: Stockholm, Laurentius Salvius, $824 \mathrm{p}$.

Loomis, F.B., 1905, Hyopsodontidae of the Wasatch and Wind River basins: American Journal of Science, v. 19, p. 416-424.

Loomis, F.B., 1907, Wasatch and Wind River rodents: American Journal of Science, v. 23, p. 123-130.

Marsh, O.C., 1871, Notice of some new fossil mammals and birds from the Tertiary formations of the West: American Journal of Science, v. 2, p. $120-127$.

Marsh, O.C., 1872, Preliminary description of new Tertiary mammals. Parts I through IV: American Journal of Science, v. 4, p. 122-128, 202-224.

Marsh, O.C., 1875, On a new order of Eocene mammals: American Journal of Science, v. 9, p. 221.

Marsh, O.C., 1876, On some characters of the genus Coryphodon Owen: American Journal of Science, v. 3, p. 425-428.

Marsh, O.C., 1894, Description of Tertiary artiodactyls: American Journal of Science, v. 48, p. 259-274.

Matthew, W.D., 1899, A provisional classification of the fresh-water Tertiary of the West: Bulletin of the American Museum of Natural History, v. 12, p. 19-75. 
Matthew, W.D., 1901, Additional observations on the Creodonta: Bulletin of the American Museum of Natural History, v. 14, p. 1-38.

Matthew, W.D., 1903, The fauna of the Titanotherium beds at Pipestone Springs, Montana: Bulletin of the American Museum of Natural History, v. 19 , p. $197-226$.

Matthew, W.D., 1909, Carnivora and Insectivora of the Bridger Basin, middle Eocene: Memoirs of the American Museum of Natural History, v. 9 , p. 291-567.

Matthew, W.D., 1915a, A revision of the Lower Eocene Wasatch and Wind River faunas. Part II. Order Condylarthra, Family Hyopsodontidae: Bulletin of the American Museum of Natural History, v. 34, p. 311-328.

Matthew, W.D., 1915b, A revision of the lower Eocene Wasatch and Wind River faunas: Part IV. Entelonychia, Primates, and Insectivora (Part): Bulletin of the American Museum of Natural History, v. 34, p. 429-483.

Matthew, W.D., 1918, A revision of the Lower Eocene Wasatch and Wind River faunas. Part V. Insectivora (continued), Glires, Edentata: Bulletin of the American Museum of Natural History, v. 38, p. 565-657.

Matthew, W.D., 1920, A new genus of rodents from the middle Eocene: Journal of Mammalogy, v. 1, p. 168-169.

Matthew, W.D., 1929, Preoccupied names: Journal of Mammalogy, v. 10, p. 171.

Matthew, W.D., 1937, Paleocene faunas of the San Juan Basin, New Mexico: Transactions of the American Philosophical Society, v. 30, p. 1-510.

McKenna, M.C., 1975, Toward a phylogenetic classification of the Mammalia, in Luckett, W.P., and Szalay, F.S., eds., Phylogeny of the Primates, New York, Plenum Press, p. 21-46.

McKenna, M.C., and Bell, S.K., 1997, Classification of Mammals Above the Species Level, New York, Columbia University Press, 631 p.

Miller, G.S., and Gidley, J.W., 1918, Synopsis of the supergeneric groups of rodents: Journal of the Washington Academy of Sciences, v. 8 , p. $431-448$

Muldoon, K.M., and Gunnell, G.F., 2002, Omomyid primates (Tarsiiformes) from the early middle Eocene at South Pass, Greater Green River Basin, Wyoming: Journal of Human Evolution, v. 43, p. 479-511.

Nachman, B., Beard, K.C., and Anemone, R., 2010, New Primates (Omomyidae) from the Great Divide Basin, Wyoming: Journal of Vertebrate Paleontology, Program and Abstracts, v. 2010, p. 138A.

Nelson, M.E., 1973, Age and stratigraphic relations of the Fowkes Formation, Eocene of southwestern Wyoming and northeastern Utah: Contributions to Geology, University of Wyoming, v. 12, p. 27-31.

Novacek, M.J., 1977, A review of Paleocene and Eocene Leptictidae (Eutheria: Mammalia) from North America: PaleoBios, v. 24, p. 1-42.

Novacek, M.J., 1982, Diacodon alticuspis, an erinaceomorph insectivore from the early Eocene of northern New Mexico: Contributions to Geology, University of Wyoming, v. 20, p. 135-149.

Novacek, M.J., Bown, T.M., and Schankler, D., 1985, On the classification of the early Tertiary Erinaceomorpha (Insectivora, Mammalia): American Museum Novitates, v. 2813, p. 1-22

Oriel, S.S., and Tracy, J.I., 1970, Uppermost Cretaceous and Tertiary stratigraphy of Fossil Basin, southwest Wyoming: U.S. Geological Survey Professional Paper, v. 635, p. 1-53.

Osborn, H.F., and Wortman, J.L., 1892, Fossil mammals of the Wasatch and Wind River beds. Collected in 1891: Bulletin of the American Museum of Natural History, v. 4, p. 80-147.

Owen, R., 1845, Odontography; a treatise on the comparative anatomy of teeth, London, Hippolyte Bailliere, 655 p.

Owen, R., 1848, Description of teeth and portions of jaws of two extinct Anthracotherioid quadrupeds (Hyopotamus vectianus and Hyop. bovinus) discovered by the Marchioness of Hastings in the Eocene deposits on the NW coast of the Isle of Wight: with an attempt to develop Cuvier's idea of the Classification of Pachyderms by the number of their toes: Quarterly Journal of the Geological Society of London, v. 4, p. 103-141.

Radinsky, L., 1963, Origin and early evolution of North American Tapiroidea: Bulletin of the Peabody Museum of Natural History, v. 17, p. 1-106.

Redline, A.D., 1997, Revision of the Wind River faunas, early Eocene of central Wyoming. Part 13. Systematics and phylogenetic pattern of early Eocene Hyopsodus (Mammalia: Condylarthra): Annals of Carnegie Museum, v. 66 p. $1-81$.

Robinson, P., 1966, Fossil Mammalia of the Huerfano Formation, Eocene, of Colorado: Bulletin of the Peabody Museum of Natural History, v. 21, p. 1-95.

Rose, K.D., 1981, The Clarkforkian Land-Mammal Age and mammalian faunal composition across the Paleocene-Eocene boundary: University of Michigan Papers on Paleontology, v. 26, p. 1-197.

Rose, K.D., 2006, The Beginning of the Age of Mammals, Baltimore, The Johns Hopkins University Press, $428 \mathrm{p}$.

Rose, K.D., and Chinnery, B.J., 2004, The postcranial skeleton of early Eocene rodents: Bulletin of Carnegie Museum of Natural History, v. 36, p. 211-244.
Rose, K.D., and Von Koenigswald, W., 2007, The marmot-sized paramyid rodent Notoparamys costilloi from the early Eocene of Wyoming, with comments on dental variation and occlusion in paramyids: Bulletin Carnegie Museum of Natural History, v. 39, p. 111-125.

Rothecker, J., and Storer, J.E., 1996, The marsupials of the Lac Pelletier Lower Fauna, middle Eocene (Duchesnean) of Saskatchewan: Journal of Vertebrate Paleontology, v. 16, p. 770-774.

Savage, D.E., and Waters, B.T., 1978, A new omomyid primate from the Wasatch Formation of southern Wyoming: Folia Primatologica, v. 30, p. 1-29.

Scott, W.B., and Jepsen, G.L., 1936, The mammalian fauna of the White River Oligocene-Part I. Insectivora and Carnivora: Transactions of the American Philosophical Society (New Series), v. 28, p. 1-153.

Simons, E.L., 1962, A new Eocene primate genus, Cantius, and a revision of some allied European lemuroids: Bulletin, British Museum of Natural History (Geology), v. 7, p. 1-36.

Simons, E.L., 1972, Primate Evolution, an introduction to man's place in nature, New York, Macmillan, 322 p.

Simpson, G.G., 1928, American Eocene didelphids: American Museum Novitates, v. 307, p. $1-7$.

Simpson, G.G., 1940, Studies on the earliest primates: Bulletin of the American Museum of Natural History, v. 77, p. 185-212.

Simpson, G.G., 1954, An apatemyid from the early Eocene of New Mexico: American Museum Novatates, v. 1654, p. 1-4.

Sinclair, W.J., 1914, A revision of the bunodont Artiodactyla of the middle and lower Eocene of North America: Bulletin of the American Museum of Natural History, v. 33, p. 267-295.

Strait, S.G., 2001, New Wa-0 mammalian fauna from Castle Gardens in the southeastern Bighorn Basin, in Gingerich, P.D., ed., Paleocene-Eocene Stratigraphy and Biotic Change in the Bighorn and Clarks Fork Basins, Wyoming: University of Michigan, Papers on Paleontology, v. 33, p. 127-143.

Stucky, R.K., 1984, Revision of the Wind River faunas, early Eocene of central Wyoming. Part 5. Geology and biostratigraphy of the upper part of the Wind River Formation, northeastern Wind River Basin: Annals Carnegie Museum, v. 53, p. 231-294.

Stucky, R.K., and Krishtalka, L., 1990, Revision of the Wind River faunas, early Eocene of central Wyoming. Part 10. Bunophorus (Mammalia, Artiodactyla): Annals of Carnegie Museum, v. 59, p. 149-171.

Szalay, F.S., 1976, Systematics of the Omomyidae (Tarsiiformes, Primates): taxonomy, phylogeny, and adaptations: Bulletin of the American Museum of Natural History, v. 156, p. 159-449.

Szalay, F.S., and Delson, E., 1979, Evolutionary History of the Primates, New York, Academic Press, $580 \mathrm{p}$.

Thewissen, J.G.M., 1990, Evolution of Paleocene and Eocene Phenacodontidae (Mammalia, Condylarthra): University of Michigan Papers on Paleontology, v. 29, p. 1-107.

Thewissen, J.G.M., and Gingerich, P.D., 1989, Skull and endocranial cast of Eoryctes melanus, a new palaeoryctid (Mammalia: Insectivora) from the early Eocene of western North America: Journal of Vertebrate Paleontology, v. 9, p. 459-470.

Thorpe, M.R., 1934, Meniscotherium robustum sp. nov. and a discussion of Hyracops socialis Marsh: American Journal of Science, v. 27, p. 401-409.

Thorpe, M.R., 1938, Wyoming Eocene fishes in the Marsh collection: American Journal of Science, v. 36, p. 279-295.

Trouessart, E.-L., 1879, Catalogue des mammifères vivants et fossiles. I. Primates: Revue et Magasin de Zoologie (Paris), v. 6, p. 108-140, 162-169.

Turner, H.N. Jr., 1849, On the evidence of affinity afforded by the skull in the ungulate Mammalia: Proceedings of the Zoological Society, London, v. 1849 , p. $147-158$

Uhen, M.D., and Gingerich, P.D., 1995, Evolution of Coryphodon (Mammalia, Pantodonta) in the late Paleocene and early Eocene of northwestern Wyoming: Contributions from the Museum of Paleontology, University of Michigan, v. 29, p. $259-289$

Van Valen, L., 1966, Deltatheridia, a new order of mammals: Bulletin of the American Museum of Natural History, v. 132, p. 1-126.

Van Valen, L., 1967, New Paleocene insectivores and insectivore classification: Bulletin of the American Museum of Natural History, v. 135, p. 219-284.

Van Valen, L., 1971, Adaptive zones and the orders of mammals: Evolution, v. 25 , p. $420-428$.

Weber, M., 1904, Die Säugetiere. Einführing in die Anatomie und Systematik der recenten und Fossilen Mammalia, Jena, Gustav Fischer, 866 p.

West, R.M., 1973, Geology and mammalian paleontology of the New Fork-Big Sandy Area, Sublette County, Wyoming: Fieldiana Geology, v. 29, p. 1-193.

Winge, H., 1917, Udsigt over Insektaedernes indbyrdes Slaegtskab: Videnskabelige Meddelelser Dansk Naturhistorisk Forening, Copenhagen, v. 68 p. 83-203.

Wood, A.E., 1962, The Early Tertiary rodents of the family Paramyidae: Transactions of the American Philosophical Society, v. 52, p. 1-261. 
Wood, A.E., 1965, Small rodents from the early Eocene Lysite Member, Wind River Formation of Wyoming: Journal of Paleontology, v. 39, p. 124-134.

Woodburne, M.O., Gunnell, G.F., and Stucky, R.K., 2009, Land mammal faunas of North America rise and fall during the Early Eocene Climatic Optimum: Denver Museum of Nature \& Science Annals, v. 1, p. 1-74.

Wortman, J.L., 1886, Species of Hyracotherium and allied perissodactyls from the Wahsatch and Wind River Beds of North America: Bulletin of the American Museum of Natural History, v. 8, p. 81-110.

Wortman, J.L., 1903, Studies of Eocene Mammalia in the Marsh collection, Peabody Museum. Part II. Primates, Suborder Cheiromyoidea: American Journal of Science, v. 16, p. 345-368.

Wortman, J.L., and Matthew, W.D., 1899, The ancestry of certain members of the Canidae, the Viverridae, and Procyonidae: Bulletin of the American Museum of Natural History, v. 12, p. 109-139.
Zonneveld, J.-P., Gunnell, G.F., and Bartels, W.S., 2000, Early Eocene fossil vertebrates from the southwestern Green River Basin, Lincoln and Uinta Counties, Wyoming: Journal of Vertebrate Paleontology, v. 20 , p. $369-386$.

Zonneveld, J.-P., Lavigne, J.M., Bartels, W.S., and Gunnell, G.F., 2006, Lunulichnos tuberosus (ichnogen. and ichnosp. nov.) from the Early Eocene Wasatch Formation, Fossil Butte National Monument, Wyoming: an arthropod-constructed trace fossil associated with alluvial firmgrounds: Ichnos, v. 13, p. 87-94.

Accepted 18 April 2016 